\title{
Digital Draw Connections. La sfida culturale della rappresentazione della complessità e contraddizioni nel paesaggio
}

\author{
Fabio Bianconi \\ Marco Filippucci
}

\section{Abstract}

II presente studio propone i risultati di una canonica 'call for paper', mettendo in evidenza l'impatto culturale di carattere internazionale insito nella costruzione di un dibattito scientifico sul tema delle connessioni. Al centro è posto il valore della rappresentazione come luogo di esistenza dei diversi saperi e campo dell'interpretazione delle implicite relazioni insite fra i segni architettonici, il suo ambiente e l'uomo. In particolare si vuole riconoscere nella scala più estesa del paesaggio la centralità dell'opera di Robert Venturi sulla complessità e contraddizioni dell'architettura, per entrare sulle questioni rappresentative. Se quindi da un lato la proposta vuole fornire una chiave ermeneutica di lettura degli attuali studi sul paesaggio in rapporto agli ambiti rappresentativi, dall'altro lato la stessa impatta sulla critica architettonica nella rilettura di un approccio metodologico che ha segnato la storia e continua a mostrare il suo valore nelle connessioni sempre nuove.

Parole chiave

rappresentazione, percezione, paesaggio, storia, narrazione.

\section{Digital Draw Connections REPRESENTING COMPLEXITY \\ AND \\ CONTRADICTION IN LANDSCAPE

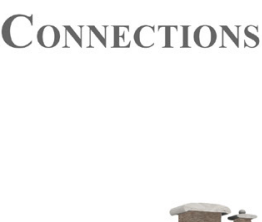

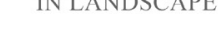


Fig. I. Nuove connessioni fra Porta Pia immortalata nella copertina del volume di Robert Venturi e la complessità e contraddizione dell'attuale paesagrio con i suoi nuovi significti con bene tutelato.

\section{Una proposta culturale}

Il presente studio propone i risultati di un approccio di ricerca decisamente poco innovativo nella sua metodologia, che si basa sulla costruzione di una call for paper, un percorso prettamente 'classico', insito nelle logiche della ricerca scientifica. La sua canonicità però non contrasta con il suo valore, sulla possibilità di creare connessioni virtuali fra studiosi e temi d'indagine, attraverso comuni riflessioni che divengono implicitamente una proposta culturale unica, basata su impianti pluridisciplinari che mettono in evidenza le conoscenze e le relazioni che si aprono sulle questioni poste in essere.

Nella tesi che tale proposta sia foriera di un pensiero culturale che impatta fino alla scala internazionale, il tema proposto si concentra nel disegno delle connessioni insite nel paesaggio, così valutato nella molteplicità dei suoi significati, come complesso e contradditorio, ambiguo e inclusivo. All'interno della call si marca una strutturale definizione del paesaggio nel campo rappresentativo, correlato alla percezione, forma pensata, vista nel pensiero" [De Fiore 1967, p. 9], disegno che sin dal Trecento Cennino Cennini vedeva redatto "dentro la testa" [Cennini 2003, p. I5], 'disegno interno' di Federico Zuccari che genera il 'disegno esterno' [Zuccaro 196I].

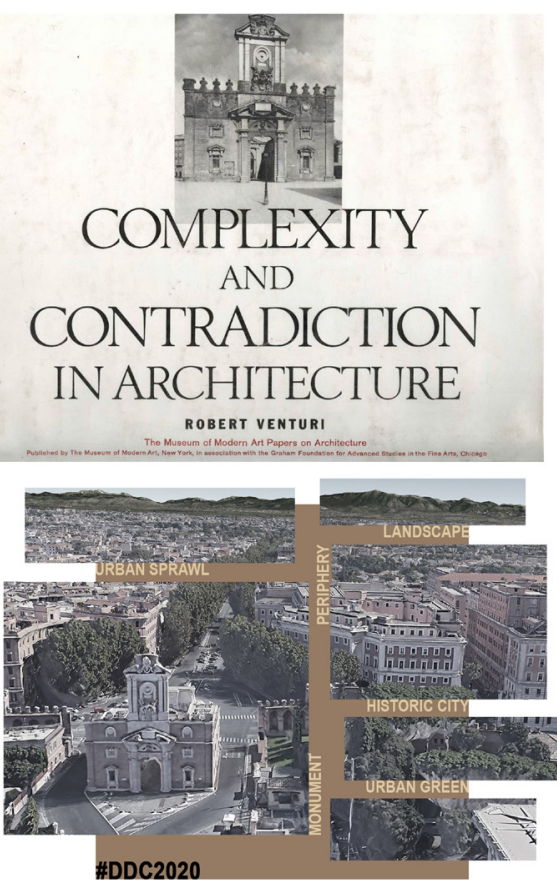

La proposta culturale trova la sua forza nella reinterpretazione dell'opera di Robert Venturi sulla complessità e contraddizione dell'architettura, estendendone il valore nella scala e nell'ambivalenza del rapporto fra virtualità e realtà insito nella rappresentazione del paesaggio. L'opera del grande maestro americano, il suo 'manifesto gentile' [Venturi 1967], viene reinterpretato per comprendere una metodologia di lettura del paesaggio, che vuole essere liberato dai riduttivismi delle semplificazioni del pittoresco, una delle questioni che più aggravano le politiche di governo del territorio.

Il paesaggio, inteso come processo culturale e specchio dell'identità sociale di un luogo, sempre con più chiarezza svela la sua connaturale struttura relazionale. II legame fra segni e molteplicità di significati, la dialettica fra natura e artificio, il rapporto fra narrazione e ideazione, sono solo sezioni di una totalità di nessi che esplicano quel rapporto che il paesaggio ha con l'ambiente e il territorio, tre ambiti che possono essere associati alla triade vitruviana portando "inevitabilmente alla complessità e contraddizione" [Venturi 1967, p. 16]. 
Fig. 2. Connessioni di ricerca fra i temi venturiani e le questioni rappresentative proposte nel volume.
In tale contesto la rappresentazione si pone come strumento interpretativo e come luogo dei modelli. Nella definizione, selezione, astrazione ed evocazione insite del disegno, il paesaggio trova esemplificazioni che ne esaltano una narrazione pittoresca implicitamente foriera di fraintendimenti e banalizzazioni. Ma la stessa rappresentazione nasconde a volte, nei suoi diversi livelli di lettura, una ben più ricca interpretazione, velata a chi non entra nel suo percorso, una nuova dimensione che si relaziona con il reale giustapponendo ulteriori livelli di complessità e contraddizione, rafforzando ancora la logica della 'sovradiacenza' per cui "Il più non vale di meno" (more is not less) [Venturi 1967, p. I6].

Le ricerche sul paesaggio vogliono riguardare 'verticalmente' i grandi temi paradigmatici nelle loro complessità e contraddizioni ma anche 'orizzontalmente' temi minori volti a narrare quel carattere inclusivo del paesaggio, vitale e comunque paradossalmente carico di una sua qualità anche in quanto "ibrido, compromesso, distorto, ambiguo, noioso, convenzionale, accomodante, ridondante, rudimentale, inconsistente, equivoco" [Venturi 1967, p. I6]. Le complessità e contraddizioni nel paesaggio si legano poi alla lettura diacronica insita nella stratificazione di segni e significati, nell'interpretazione dei valori, un tema che porta a ricercare alla radice le ragioni degli attuali risultati e delle compromissioni subite, ma che apre anche a considerazioni filologiche sull'impatto delle ricerche di Venturi. Senza mai scordare "I'impegno a tendere verso l'unità difficile" [Venturi 1967, p. I6], la complessità e contraddizione del paesaggio vuole aprirsi a tematiche socio-culturali di grande attualità e vasta portata, che riguardano, tra le altre cose, le questioni insite nel tema dell'identità espressa nel paesaggio, il ruolo delle immagini e il valore della percezione nel mondo trasformato dal digitale, l'individuazione di elementi identitari, quasi 'transizionali', del paesaggio e in generale il suo bilanciamento con il territorio e l'ambiente che porta a ricomporre quella sua totalità nella narrazione dei nostri luoghi, grande tema di una politica operativa sui beni comuni.

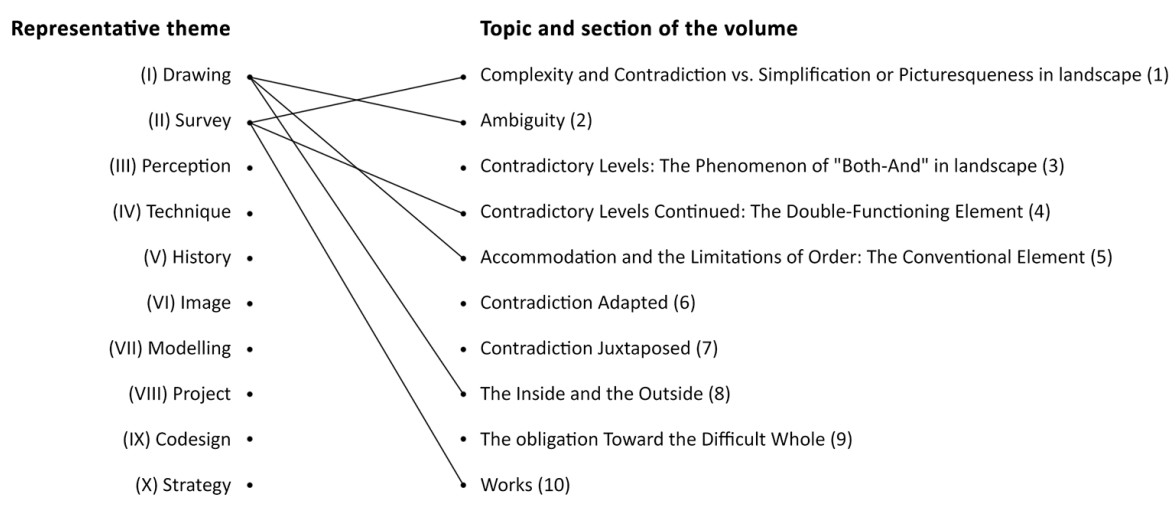

\section{I risultati della proposta}

II volume è composto da 43 saggi, di 81 autori di tutti i continenti, provenienti da 30 università, di cui 17 italiane. Gli articoli sono suddivisi in quattro parti, una prima sezione che analizza il tema del paesaggio nella società contemporanea in rapporto alle categorie interpretative proposte da Robert Venturi, una seconda che ne marca le questioni metodologiche e strumentali in rapporto anche al valore della rappresentazione e del digitale, una terza parte che rilegge i differenti paesaggi del mondo e l'estetica progettuale in funzione della complessità e contraddizione, e infine un'ultima raccolta dove si vuole tornare in Italia, guidati dalle parole di Robert Venturi per entrare nelle qualità e nei significati dei molteplici paesaggi, così ricchi del valore della stratificazione del tempo.

Impressionante a riguardo le molteplici interpretazioni che convergono comunque su direzioni analoghe di illustri autori come Franco Purini, Franco Zagari, Denise Rae Costanzo, Carolina Vaccaro, Rosalea Monacella, Bridget Keane, Pilar Chías, Mario Torelli, nonché quasi 
cinquanta studiosi afferenti all'area del disegno: per tutti c'è una sostanziale riscoperta della contemporaneità del pensiero di Robert Venturi come reale anticipazione delle questioni paesaggistiche, in quegli anni del tutto ignorate. Inoltre ci sono similari concezioni di paesaggio, nelle sue molteplicità di forme, sempre complesso e contraddittorio, dove le connessioni sono la strutturalmente l'essenza stessa di ciò che esiste solo come teoria, nel senso etimologico del rapporto fra 'vedere' e 'pensare', nell'impatto dell'ambiente per l'uomo.
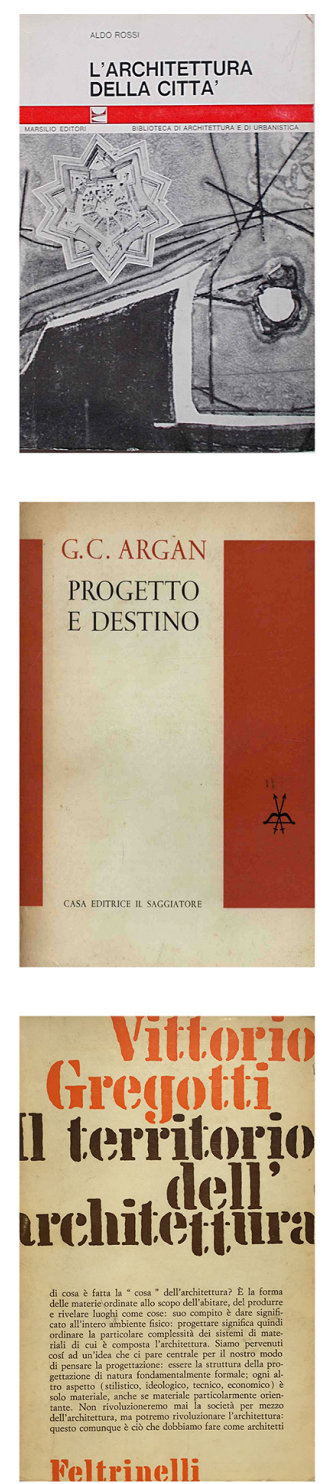
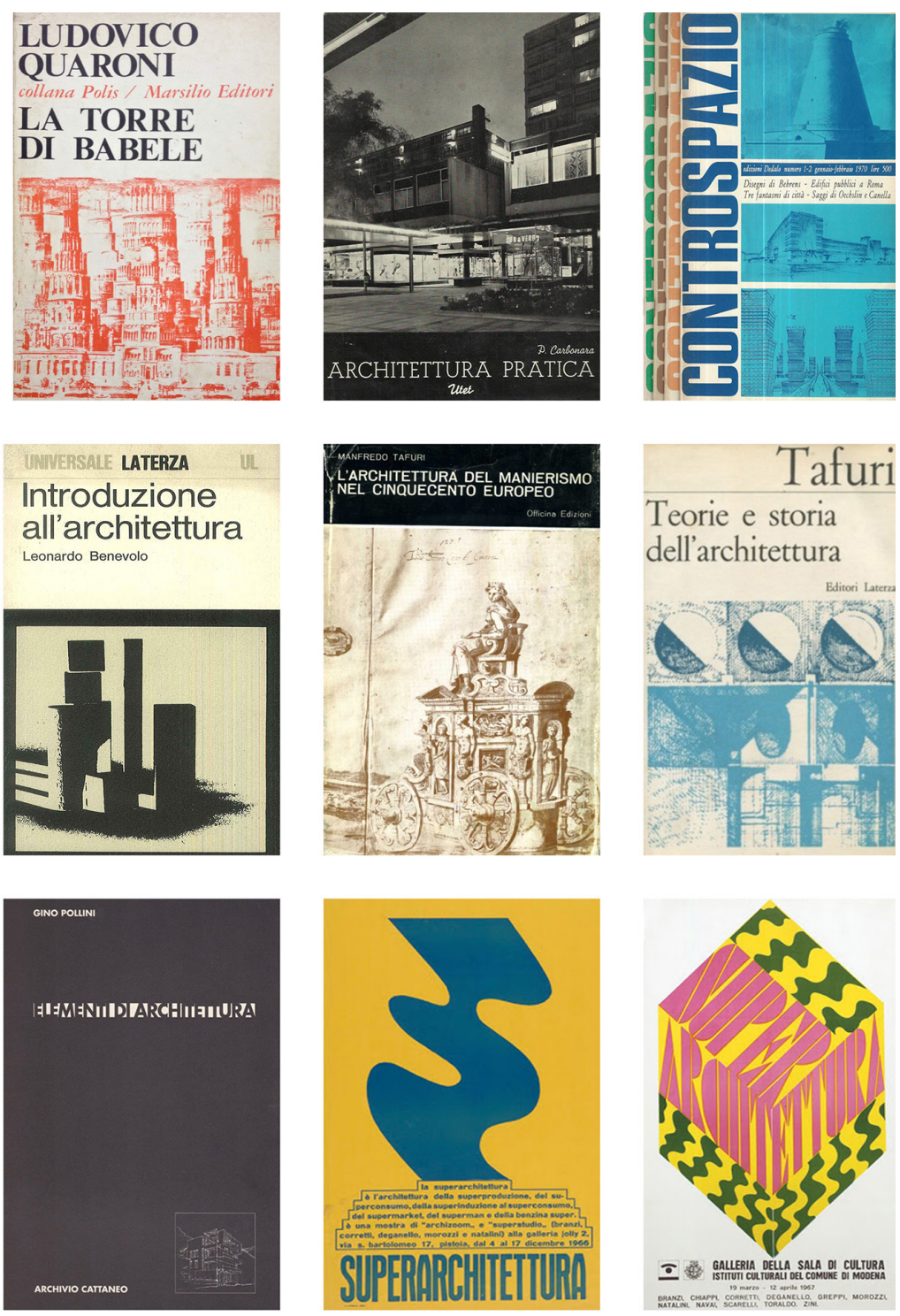

\section{Le connessioni nelle connessioni}

Questa call sulle connessioni come tema rappresentativo del paesaggio in rapporto alla rilettura del pensiero di Robert Venturi nasce dall'Umbria, ma è molto interessante, nel leggere le connessioni nelle connessioni, comprendere che il pensiero dell'allora giovane architetto americano nasce da un suo viaggio in Italia [Stierli 2007], dal fascino, l'attrazione e l'influenza [Sessa 2017] che tale paesaggio esercita su di lui, nato da padre e madre italiani [Brownlee, Venturi, Scott Brown 200 I]. 
Dalle ricerche protratte, si evince che Robert Venturi infatti si reca a Perugia in un primo viaggio nel 1948 [Weller 1985, p. I00] e su questa esperienza descrive tali città come "una bellissima città antica in una posizione incredibile adagiata sopra una sua collina da cui si vede un panorama fantastico: il paesaggio umbro è proprio quello misterioso e veramente bello. È come quello sfondo che si intravede in alcuni dipinti del XV e XVI secolo - Perugino in particolare $[\ldots]$. La combinazione di insediamenti urbani $[\ldots]$ e alberi $[. .$.$] e frutteti$ [...] e colline sfocate sullo sfondo appare come il concetto di paesaggio che può avere un bambino - o un pittore" [Sessa 2017, p. I31]. A questa prima visita seguirà poi il più lungo soggiorno dal 1954 al 1956 [Milovanovic-Bertram 2007] presso la American Accademy, prestigioso istituto che influenzerà la cultura architettonica americana [Costanzo 2009; Valentine, Valentine 1973], e anche in questo periodo visiterà l'Umbria, sottolineando ancora il suo paesaggio: "Il paesaggio umbro, che è fantastico - in qualche modo il risultato dell'utilizzo di tutto il paesaggio per scopi funzionali di carattere agricolo - si adatta con grazia. Questa area e le sue città collinari, come Assisi e Perugia, richiamano alla mente il commento di Frank Lloyd Wright:'Di gioia di vivere, c'è una prova più grande in Italia. Gli edifici [...] sembrano nascere come fiori sul ciglio della strada'. [... . Ci ispirano con la medesima musica della vita. Nessun edificio veramente italiano sembra a disagio in Italia. Tutti si accontentano felicemente del loro ornamento e colore portano con la stessa naturalezza delle rocce e degli alberi [...]. Ovunque il cipresso si alza come il tocco di una bacchetta magica, si risolve tutto in una composizione armoniosa e completa" [Sessa 20 I7, p. I42].

Fig. 4. Sconnessioni fra limmagine pittoresca dell Umbria delle incision ottocentesche e la costruzione del paesaggio di inizio Novecento realizzata attraverso il lavoro dell'uomo.
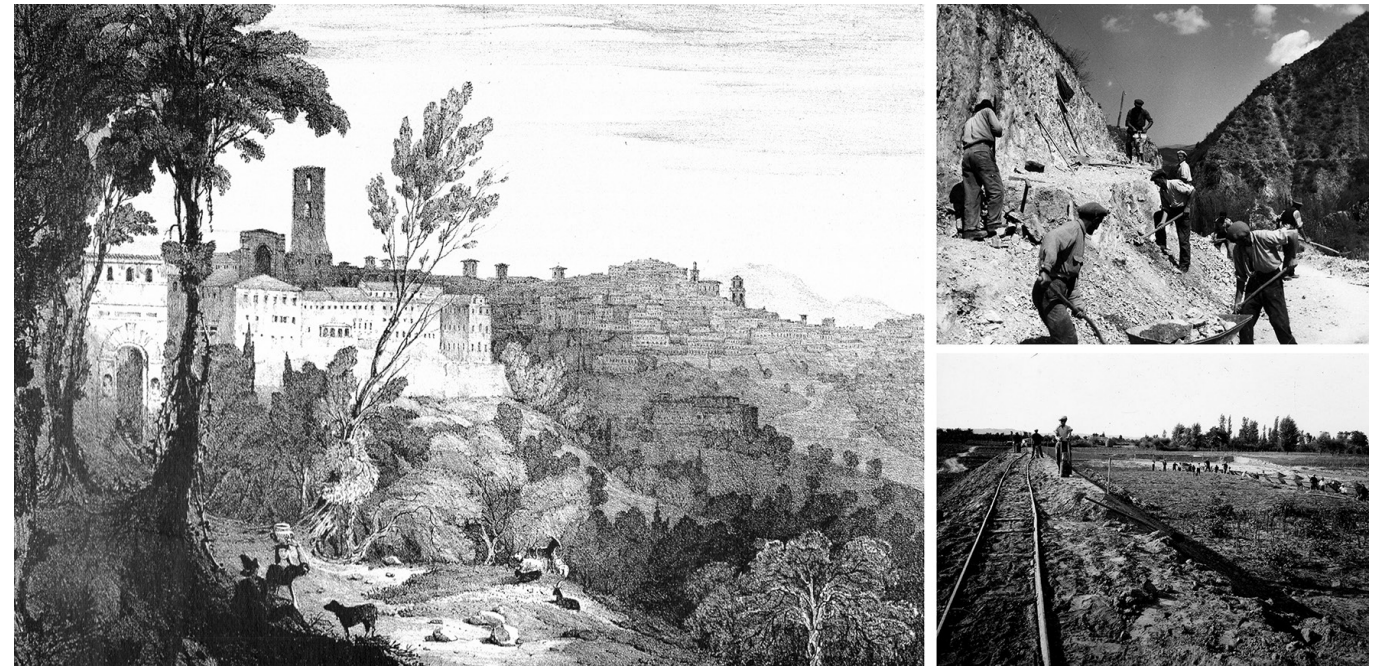

Con tendenziosità, si può affermare che Robert Venturi trovi in questa regione un luogo speciale che porta a far nascere riflessioni profonde su paesaggio. L'Umbria ha arricchito gli occhi del maestro americano di immagini che hanno contribuito a scrivere la storia della critica architettonica, e che oggi rivendicano la loro genesi seduttiva.

Nella stratificazione di segni e significati, tali luoghi sono stati certamente dei 'maestri' di Robert Venturi, che ha imposto implicitamente un confronto con le immagini della memoria dei luoghi da lui visti o immaginati [Milovanovic-Bertram 2007, p. 5]. Paradossalmente i paesaggi di quegli anni erano profondamente 'pittoreschi', connotati da grandi contraddizioni, ricchi di preesistenze storiche che oggi sarebbero state considerate con maggiore rispetto, ma che allora erano affrontate anche con grande ironia dal dinamismo popolare dello spontaneismo così ben narrato dalle immagini di Pier Paolo Pasolini ma anche oggi da Matera, ascritta ad oggi come capitale europea della cultura 2019 perché salvata dalla "estetica della povertà" nel riuso adattivo dei suoi paesaggi [Arminio 2013]. 
Libero da quel rapporto affettivo che condiziona chi vive il proprio paesaggio nativo, certamente influenzato dall'interpretazione fenomenologica di Jean Labatut [Scott Brown 1984, pp. 69-8I] con il suo approccio prevalentemente visivo [Otero-Pailos 20 I0, p. 28], i temi aperti da Robert Venturi si mostrano oggi estremamente contemporanei, nella complessità della percezione, la contraddizione insita nelle immagini che si replicano e si esaltano nei media e nei loro linguaggi, le relazioni immateriali sottese, la molteplicità di significati che contesta le visione dogmatiche precostituite.

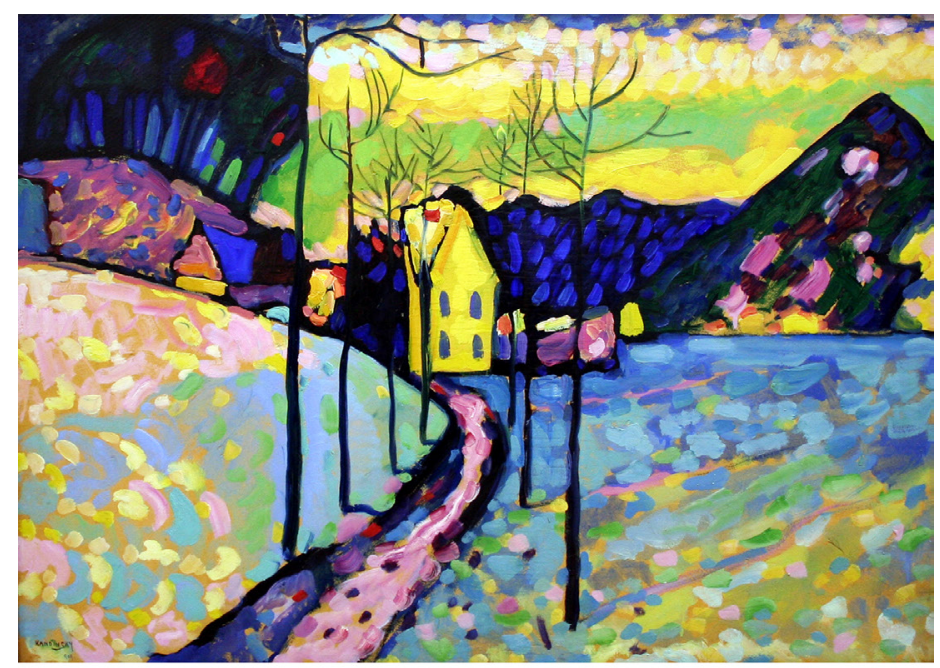

Fig. 5. Connessioni artistiche fra le reinterpretazioni del paesaggio di Kandinsky (1909) e Mondrian (1911).

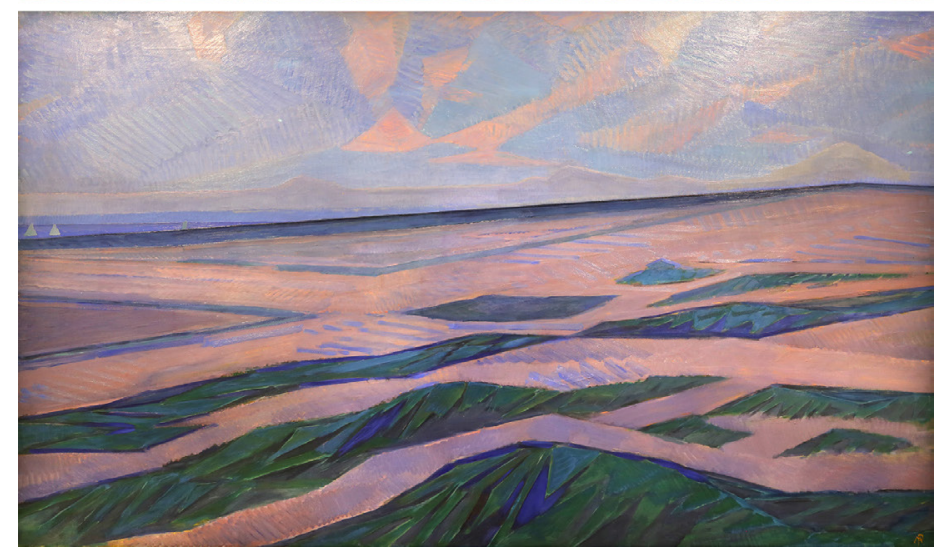

L'altra impressionante connessione nelle connessioni è inerente alla critica architettonica coeva a Venturi. In particolare si vuole mettere in evidenza che la prima edizione del libro di Venturi fu scritta nel periodo 1962-1964 e apparve in una nuova serie chiamata Papers on Modern Architecture pubblicata sotto l'imprimatur del Museum of Modern Art (MoMa) di New York nel 1966 [Ockman 20 I6]. Non è un caso che esistano delle impressionanti connessioni culturali con quanto accade in quell'esatto anno nelle università italiane: a Venezia Aldo Rossi pubblicava L'architettura della città [Rossi 1966], un vero e proprio best seller "tradotto in quasi tutte le lingue europee, base di studio e di discussioni nelle scuole d'Europa e d'America" [Rossi 1995, p. 5]. Nella Roma zeviana, Ludovico Quaroni pubblicava Cinque capitoli di note sul disegno per la città [Quaroni 1966] da cui nascerà il celebre volume La torre di Babele [Quaroni 1967], Pasquale Carbonara ripubblicava la sua Architettura pratica [Carbonara 1966], il giovane Paolo Portoghesi fondava la rivista Controspazio (Controspazio. Mensile di architettura e urbanistica, 1966), mentre solo pochi mesi prima Giulio Carlo Argan pubblicava il suo grande lavoro Progetto e destino [Argan 1965]. Sempre in quell'anno Leo- 
nardo Benevolo ripubblicava la sua Introduzione all'architettura [Benevolo 1960a; 1966a] e il celebre La storia dell'architettura [Benevolo 1966b; 1960b], mentre Manfredo Tafuri, forse il primo ad entrare nel valore della contraddizione per l'architettura evocato implicitamente nella complessità della scala urbana attraverso l'utopia [Tafuri 1966a], scriveva L'architettura del Manierismo nel Cinquecento europeo [Tafuri 1966b], testo che anticipava di due anni il celebre Teorie e storia dell'architettura [Tafuri 1968], nel quale veniva utilizzata come copertina un disegno proprio del 1966 di Franco Purini, che proprio e ancora in quell'anno apriva il suo studio. In contemporanea a Milano Vittorio Gregotti pubblicava il celebre II territorio dell'architettura [Gregotti 1966], Gino Pollini portava alle stampe i suoi appunti sugli Elementi di architettura [Pollini 1966], mentre a Firenze, subito dopo la grande alluvione, in quell'anno veniva fondato il Superstudio e veniva inaugurata il 4 dicembre la mostra Superarchitettura di Pistoia. Non sono coincidenze, ma connessioni, nuove concezioni alla base dell'architettura e del paesaggio.
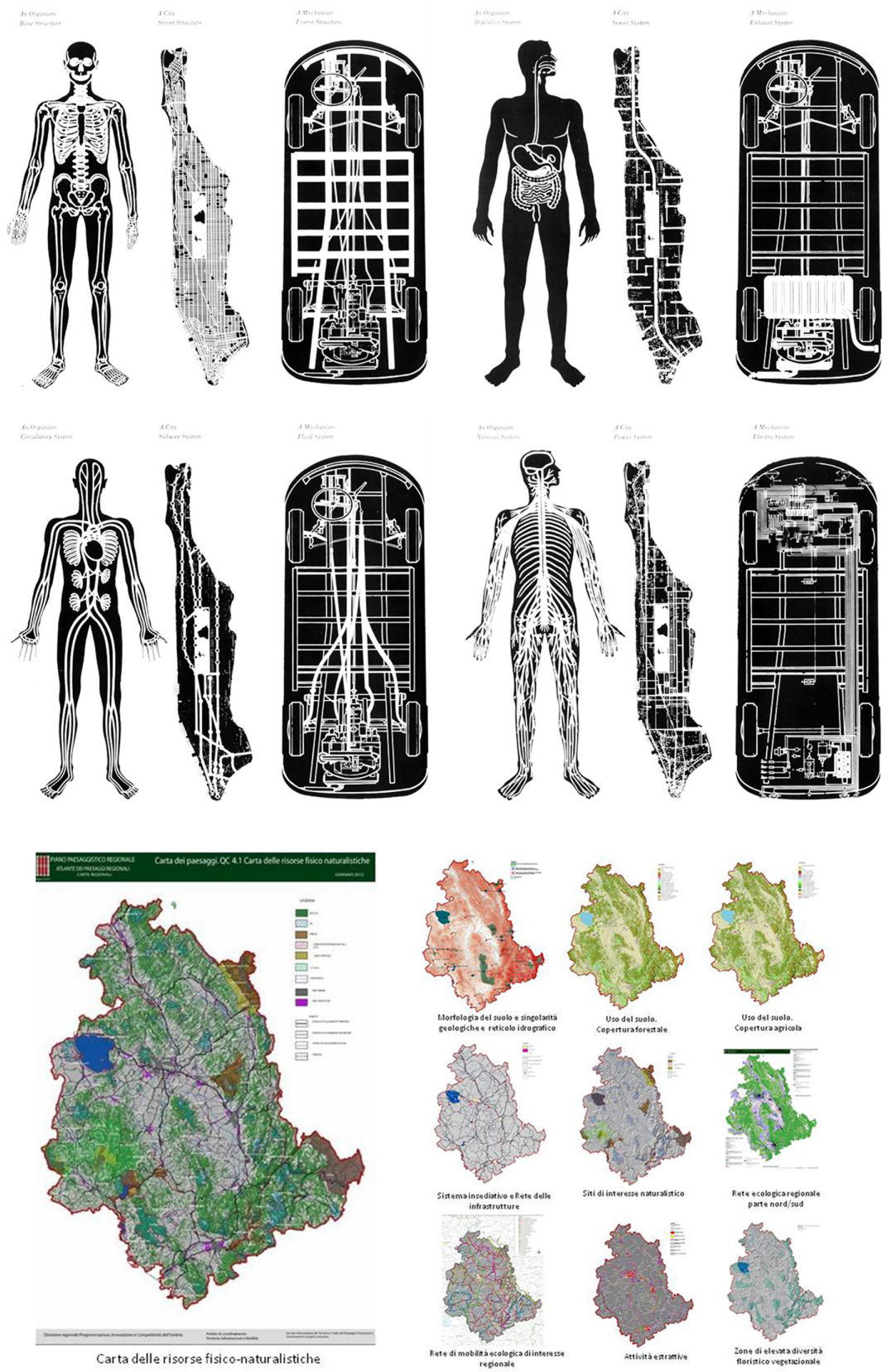

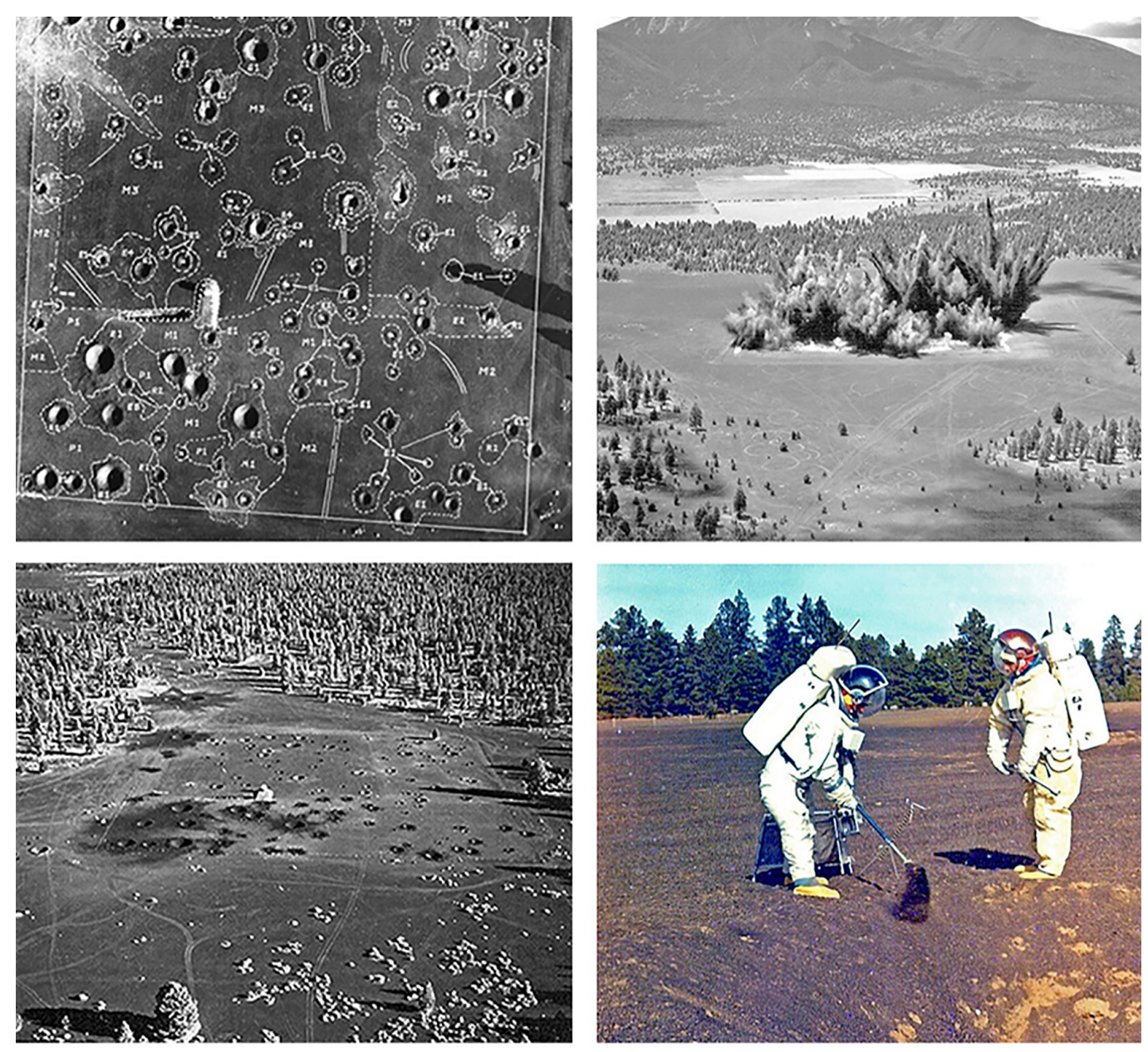

Fig. 7. Connessioni operative fra la costruzione di un paesaggio lunare artificiale e i tentativi di costruzione dell'immagine pittoresca dell'Umbria.

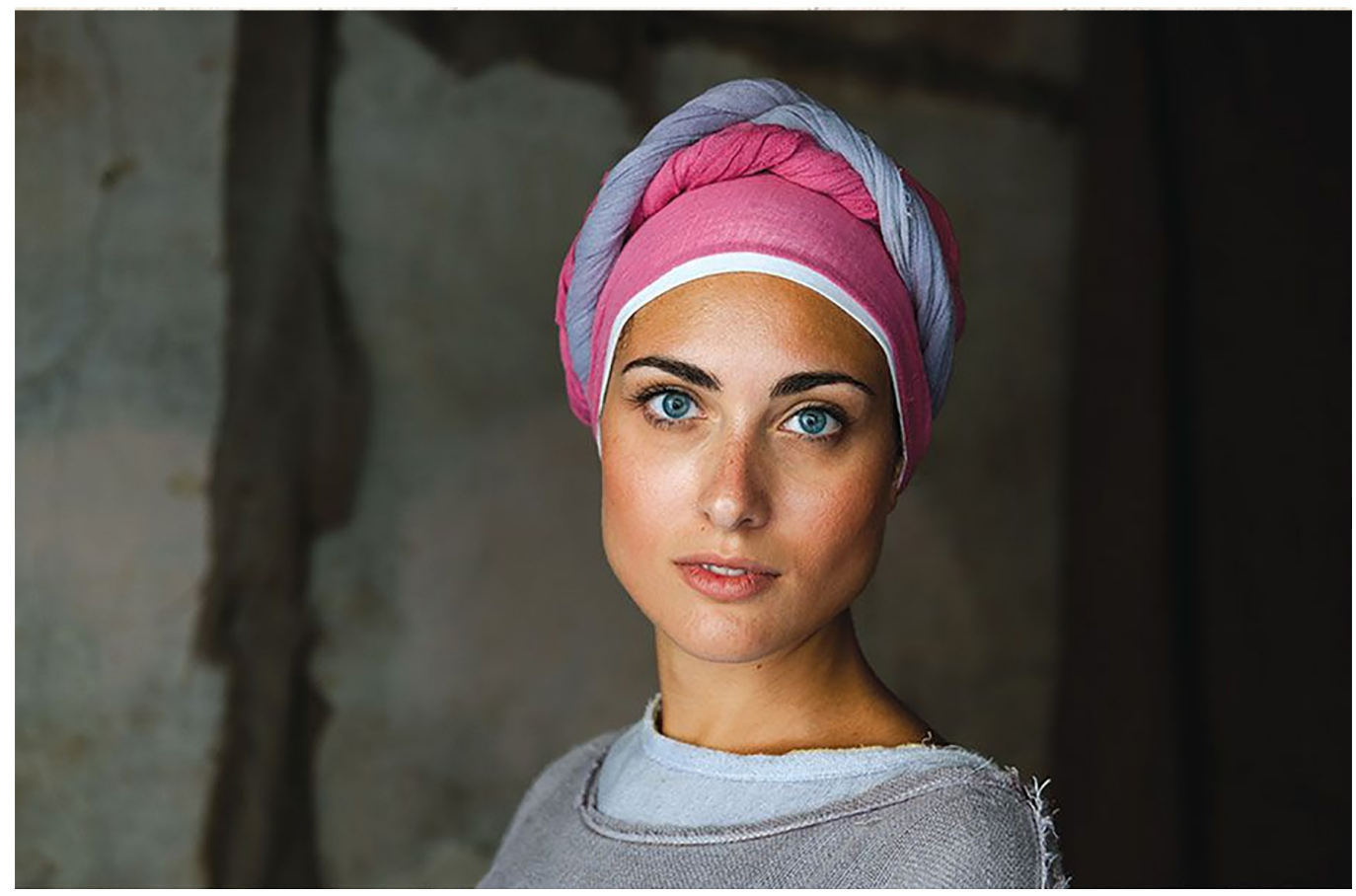


Fig 8. Connessioni mediatiche fra l'immagine e paesaggio nelle pubblicità dentro Venezia e la riproposizione implicitamente pubblicitaria diVenezia a Las Vegas.

Fig. 9. Connessioni formali fra la città come sistema segnico nel confronto fra l'equilibrio figurativo della composizione urbana

Jackson Pollock (Numbe 8, 1949)
Fig. 10. Connessioni

rappresentative fra il paesaggio urbano di Roma come ricomposizione di immagini nella acquaforte di Giovanni Battista Pir Glovanni Battista

della Forma Urbis ( 1756), e isole mnemoniche

della "città nuda" riletta

dalla teoria della deriva Guy Debord (1958) e le nalisi sociali e funzionali 1943).
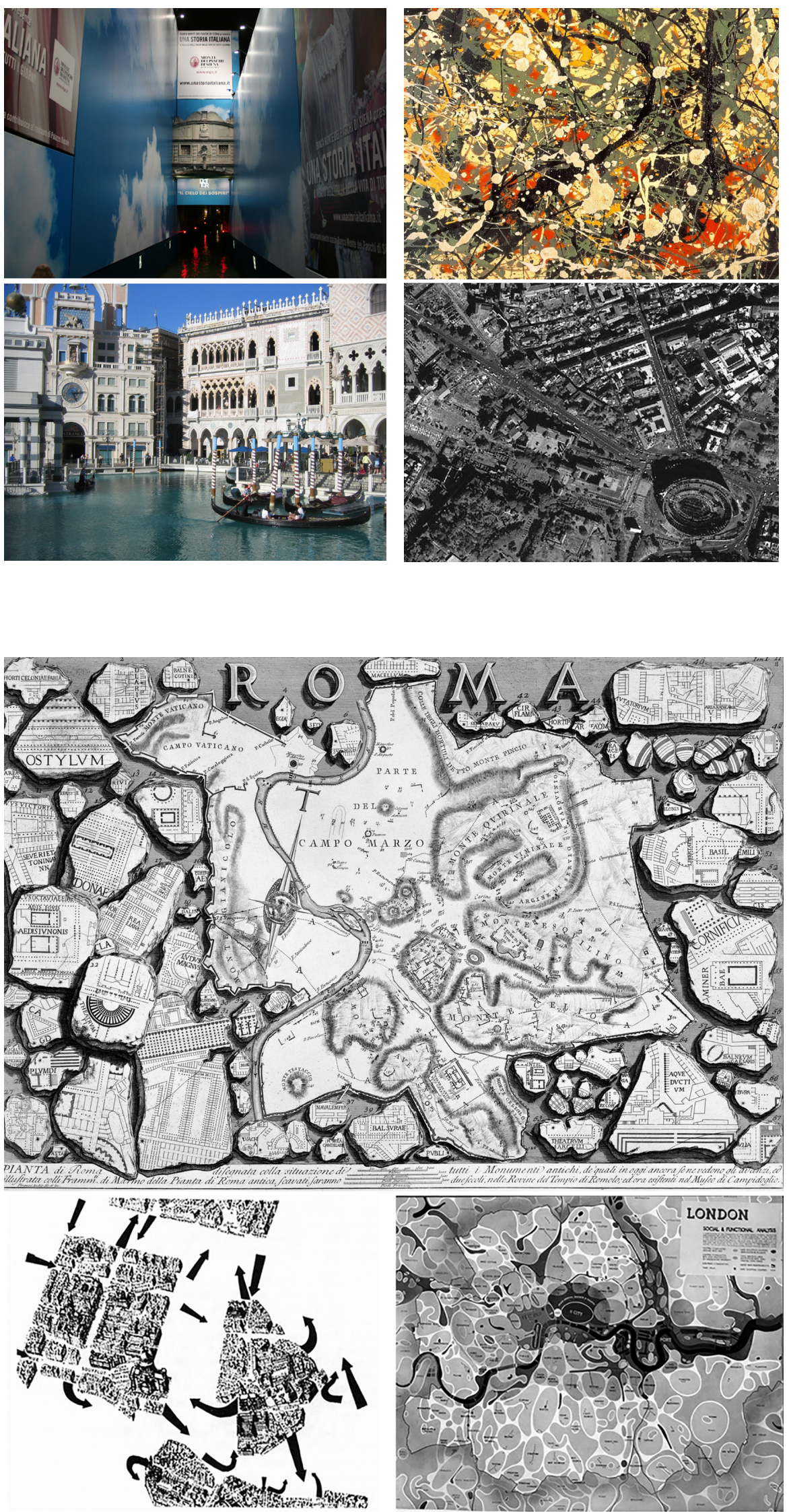


\section{Considerazioni conclusive}

Jim Venturi, figlio di Bob e Denise Scott Brown, sta preparando la presentazione del volume. La visione del giovane Robert Venturi appare come un testamento per tutta la comunità scientifica, rivalutando un'opera che con un approccio sovversivo rompe certezza e preconcetti, ma apre a riletture su questioni prettamente contemporanee. Forte del suo bagaglio culturale della centralità percettiva, le sue lezioni sempre attuali, rileggono il paesaggio correlandolo a logiche narrative, aprendo a campi di investigazione su percorsi tracciati.

Prendendo anche come caso paradigmatico la copertina di volume di Robert Venturi e la sua raffigurazione fotografica di Porta Pia, con il disegno e in particolare con il digitale si arrivano a rileggere in modo nuovo i segni nella relazione con lo spazio, con il paesaggio urbano in continua evoluzione.

Fig. I I. Connessioni e ricomposizioni semantiche nel progetto per Roma progetto per Roma del gruppo di Robert ventur John Rauch, Steven Izenour and Denise Scott Brown, 1983, Tecnica mista e collage su carta, $70 \times 50 \mathrm{~cm}$, Collezione permanente Francesco Moschini e Gabriel Vaduva, A.A.M. Architettura Arte Moderna).
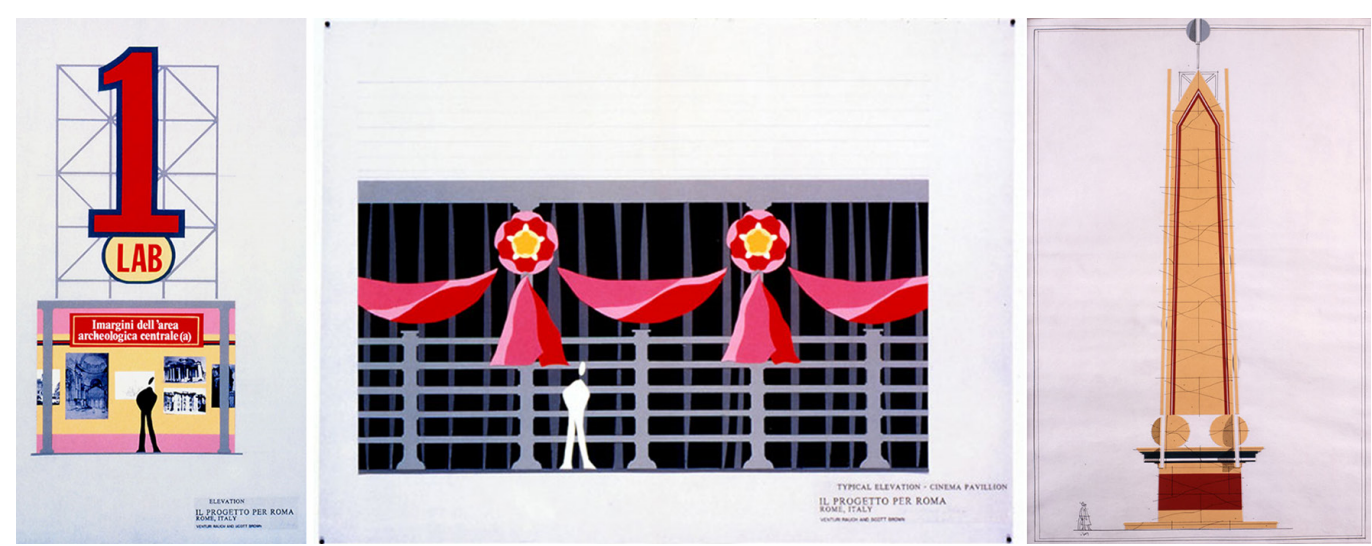

Robert Venturi non è un paesaggista, il volume si concentra sulla scala architettonica e presenta solo timidi accenni alla scala urbana, e non paesaggistica. Eppure la sua visione si apre dinamicamente alla interpretazione delle logiche contemporanee, insegnando a 'saper vedere' e si estende con disarmante semplicità per aprire a logiche operative sulle politiche sul paesaggio. Se si analizzano i piani paesaggistici, si trovano da un lato logiche vincolistiche connesse a schematizzazioni su ciò che il paesaggio dovrebbe essere, quindi su proiezioni pittoresche, che si manifestano anche nelle rappresentazioni, comunque testimonianze di una cultura, limitate a letture planimetriche, che leggono il territorio ma che in realtà raccontano poco delle qualità del paesaggio. Come contraltare, in forme dissociate, si trovano invece rappresentazioni che implicitamente esaltano il pittoresco, con un'attenzione al visivo non strutturata da informazioni. Da tali concetti conseguono le logiche di marketing territoriale e promozione prettamente turistica dove il paesaggio perde la sua qualità di bene culturale per diventare un prodotto per 'vendere i territori', con un utilizzo della seduzione dell'immagine che elide dalla tutela e dalla valorizzazione quei luoghi inadatti a riempire le copertine delle riviste.

Le ricerche rappresentative si mostrano in questo contesto per la serietà metodologica delle indagini sulle connessioni che definiscono il paesaggio. La virtualità insita nelle molteplici relazioni si sposa con il linguaggio transdisciplinare del disegno, capace di garantire la molteplicità di significati senza esimersi di entrare nella complessità e contraddizione. Le qualità del luogo si trasfigurano nel disegno nelle sue molteplici declinazioni e sperimentazioni. Nelle ricerche rappresentative che entrano nella complessità e contraddizione, che affrontano con coraggio le ambivalenze della molteplicità di significati, si aprono nuovi orizzonti di indagine per comprendere le connessioni, relazioni immateriali che ben si sposano nella logica del digitale, ma che sono la sostanza stessa del disegno, che si propone così come campo di ricerca privilegiato per le interpretazioni del paesaggio. 

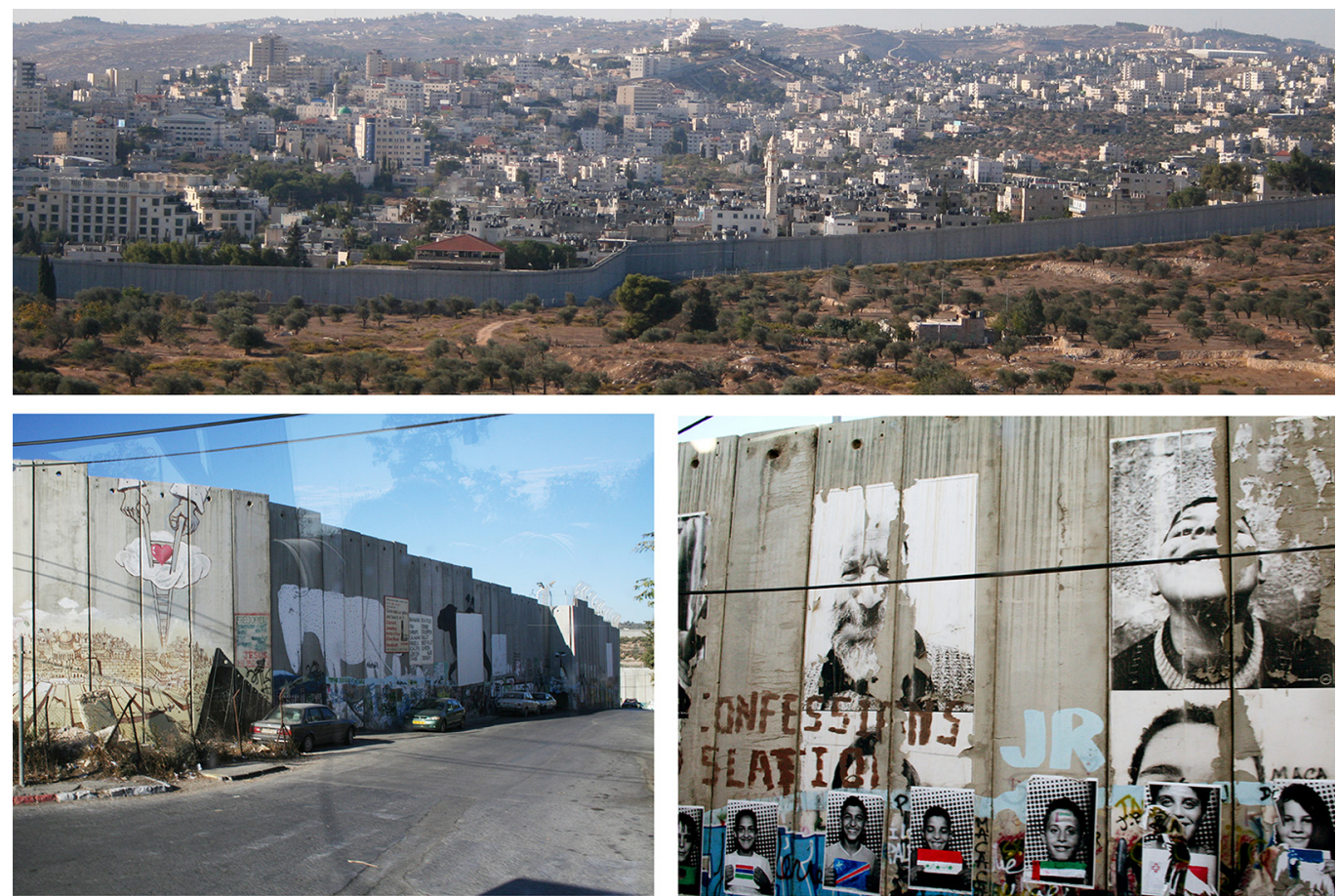

Fig. 12. Le connession della rappresentazione verso il paesaggio moderno della divisione Betlemme analisi sociali

funzionali della map

Londra (1943).
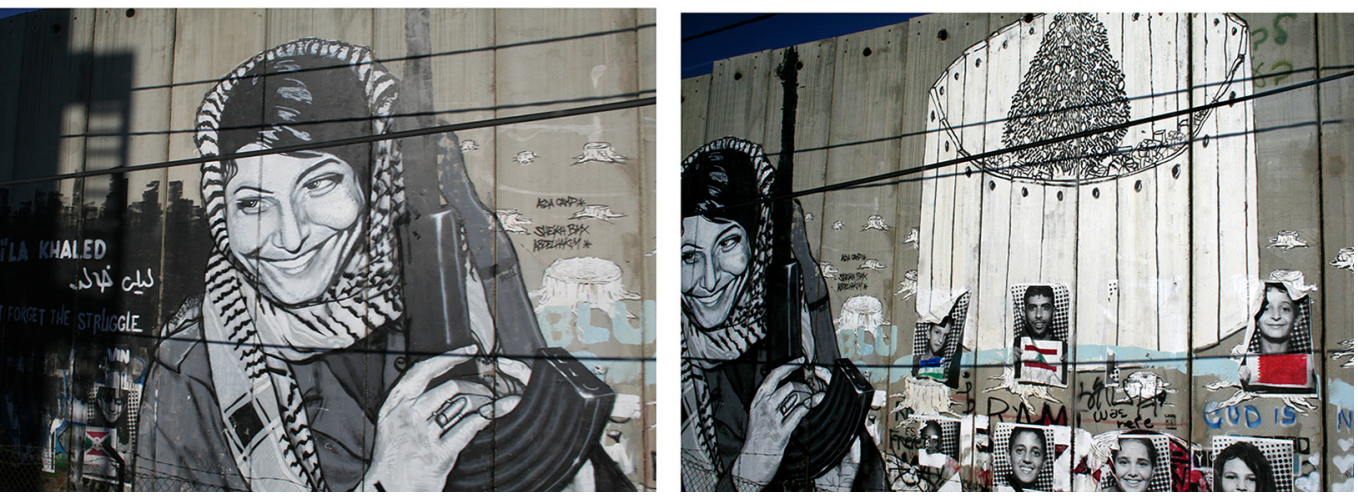

\section{Riferimenti bibliografic}

Argan Giulio Carlo (1965). Progetto e destino. Milano: il Saggiatore.

Arminio Franco (20I3). Geografia commossa dell'Italia interna. Milano: Bruno Mondadori.

Benevolo Leonardo (1960a). Introduzione all'architettura. Milano: Laterza.

Benevolo Leonardo (1960b). Storia dell'architettura moderna. Roma-Bari: Laterza.

Benevolo Leonardo (1966a). Introduzione all'architettura. Bari: Laterza.

Benevolo Leonardo (1966b). Storia dell'architettura moderna. Bari: Laterza

Brownlee David Bruce,Venturi Robert. Scott Brown Denise (eds.). (200 I). Out of the ordinary: Robert Venturi, Denise Scott Brown and Associates : architecture, urbanism, design. Philadelphia: Philadelphia Museum of Art in association with Yale University Press.

Carbonara Pasquale (1966). Architettura Pratica. Milano: UTET.

Cennini Cennino (2003). Il libro dell'arte. Milano: Neri Pozza.

Costanzo Denise Rae (2009). The Lessons of Rome: Architects at the American Academy, 1947-1966. The Pennsylvania State University.

De Fiore Gaspare (1967). La figurazione dello spazio architettonico. Genova:Vitali e Ghianda.

Gregotti Vittorio (1966). II territorio dell'architettura. Milano: Feltrinelli. 
Milovanovic-Bertram Smilja (2007). Lessons from Rome: The Works of Robert Venturi, Tod Williams, Thomas Phifer, and Paul Lewis. Rome: American Academy in Rome.

Ockman Joan (2016). Review: Complexity and Contradiction in Architecture by Robert Venturi. In Journal of the Society of Architectural Historians, I December, vol. 75, n. 4, pp. 490-492.

Otero-Pailos Jorge (2010). Architecture's historical turn: phenomenology and the rise of the postmodern. Minneapolis: University of Minnesota Press.

Pollini Gino (1966). Elementi di architettura. Milano:Tamburini.

Quaroni Ludovico (1966). Cinque capitoli di note sul disegno per la città / Ludovico Quaroni. Roma: Istituto di Architettura. Facoltà di Architettura.

Quaroni Ludovico (1967). La torre di Babele.Venezia: Marsilio.

Rossi Aldo (1966). L'architettura della città. Padova: Marsilio.

Rossi Aldo (1995). L'architettura della città. Novara: CittàStudi.

Scott Brown Denise (1984). A Worm's Eye View of Recent Architectural History. In Architectural Record, vol. I 72.

Sessa Rosa (2017). By Means of Rome. Robert Venturi: prima del Post-Modern. Università degli Studi di Napoli Federico II.

Stierli Martino (2007). In the Academy's Garden: Robert Venturi, the Grand Tour and the Revision of Modernism. In AA Files, 56, 2007, p. 42-56

Tafuri Manfredo (1966a). La nuova dimensione urbana e la funzione dell'utopia. L'Architettura. In Cronache e storia, n. I24, febbraio, p. 680-683.

Tafuri Manfredo (1966b). L'architettura del manierismo nel Cinquecento europeo. Roma: Officina Edizioni.

Tafuri Manfredo (1968). Teorie e storia dell'architettura. Milano: Laterza.

Valentine Lucia N., Valentine Alan (1973). The American Academy in Rome, 1894-1969. Charlottesville: University Press of Virginia.

Venturi Robert (1967). Complexity and Contradiction in Architecture. New York:The Museum of modern art.

Weller Anthony (1985). Travel Notes: Robert Venturi. The Golden Air of Rome. In Architectural Digest, n. 5, p. 90 - I 00.

Zuccaro Federico (196I). L'Idea de' Pittori, Scultori, et Architetti. In Zuccari Federico, Alberti Romano. Scritti d'arte di Federico Zuccaro. Firenze: Olschki.

\section{Autori}

Fabio Bianconi, Università degli Studi di Perugia, fabio.bianconi@unipg.it

Marco Filippucci, Università degli Studi di Perugia, marco.filippucci@unipg.it

Per citare questo capitolo: Bianconi Fabio, Filippucci Marco (2020). Digital Draw Connection: la sfida culturale della rappresentazione della complessità e contraddizioni nel paesaggio/Digital Draw Connections: the cultural challenge of representing complexity and contradictions in landscape. In Arena A., Arena M., Brandolino R.G., Colistra D., Ginex G., Mediati D., Nucifora S., Raffa P. (a cura di). Connettere. Un disegno per annodare e tessere. Atti del $42^{\circ}$ Convegno Internazionale dei Docenti delle Discipline della Rappresentazione/Connecting. Drawing for weaving relationships. Proceedings of the 42th International Conference of Representation Disciplines Teachers. Milano: FrancoAngeli, pp. 2981-3004. 


\title{
Digital Draw Connections. The Cultural Challenge of Representing Complexity and Contradictions on the Landscape
}

\author{
Fabio Bianconi \\ Marco Filippucci
}

\section{Abstract}

The present study proposes the results of a canonical 'call for paper', highlighting the cultural impact of an international nature inherent in the construction of a scientific debate on the topic of connections. The value of representation is the center of the research, as a place of existence of different knowledge and as a field of interpretation of the implicit relations inherent the architectural signs, its environment and man. In particular, it recognizes the centrality of Robert Venturi's work on the complexity and the contradictions of architecture, in order to enter in representative issues on the largest scale of the landscape. Therefore, if on the one hand the proposal aims to provide a hermeneutic key to read current studies on landscape in relation to the representative areas, on the other hand it impacts on architectural criticism in the reinterpretation of a methodological approach, which has marked history and continues to show its value in ever-new connections.

Keywords

representation, perception, landscape, history, narration.

\section{Digital Draw Connections REPRESENTING COMPLEXITY \\ AND \\ CONTRADICTION IN LANDSCAPE

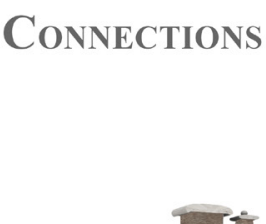

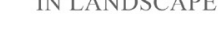


Fig. I. New connections between Porta Pia, immortalized on the cover of Robert Venturi's volume, and the complexity and contradiction of the current landscape with its new meanings of the protected good.

\section{A cultural proposal}

The present study proposes the results of a research approach, which is not very innovative in its methodology, based on the construction of a call for paper, a purely 'classic' path, inherent in the logic of scientific research. Its canonic aspect, however, does not conflict with its value, on the possibility of creating virtual connections between scholars and investigation themes, through common reflections that implicitly become a unique cultural proposal, based on multidisciplinary systems that highlight knowledge and relations opened on the issues put in place.

In the thesis that this proposal is a harbinger of a cultural thought that reaches out to the international scale, the proposed theme focuses on the design of the connections inherent in the landscape, so valued in the multiplicity of its meanings, as complex and contradictory, ambiguous and inclusive. Within the call there is a structural definition of landscape in the representative field, correlated to perception, "thought form, seen in thought" [De Fiore 1967, p. 9], a design that since the fourteenth century Cennino Cennini had seen it drawn up "inside the head" [Cennini 2003, p. I5], Federico Zuccari's 'internal design' that generates the 'external design' [Zuccaro 1961].

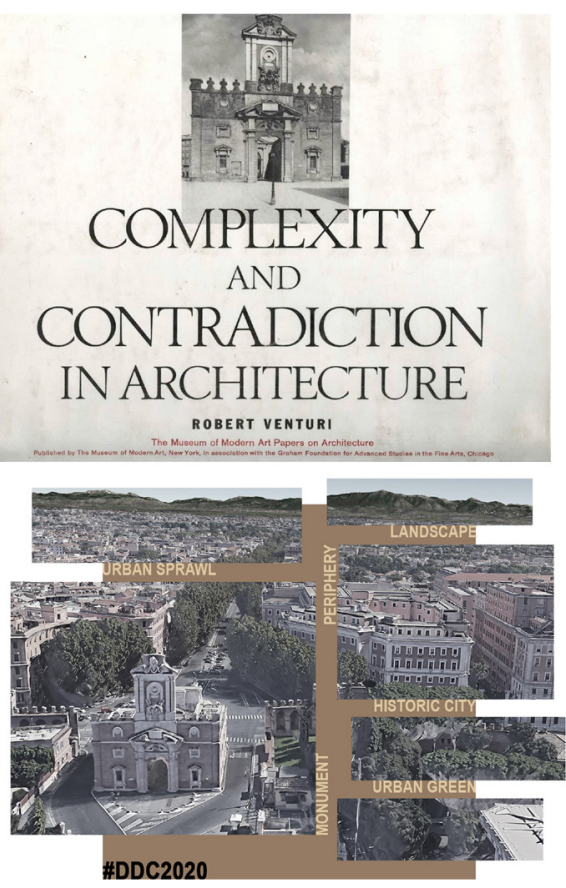

The cultural proposal finds its strength in the reinterpretation of Robert Venturi's work on the complexity and contradiction of architecture, extending its value in the scale and ambivalence of the relation between virtuality and reality, inherent in the representation of the landscape. The work of the great American master, his 'gentle manifesto' [Venturi 1967, p. I6]. is reinterpreted to understand a methodology for reading the landscape, to free it from the reductivism of the simplifications of the picturesque, one of the issues that most aggravate the territorial government policies.

The landscape, understood as a cultural process and reflecting mirror of the social identity of a place, increasingly reveals its connatural relational structure. The link between signs and multiplicity of meanings, the dialectic between nature and artifice, the relation between narration and conception, are only sections of a totality of connections that explain the relation that the landscape has with the environment and the territory; these three areas can be associated with the Vitruvian triad leading "inevitably to complexity and contradiction" [Venturi 1967, p. 16]. 
In this context, representation is an interpretative tool and a place for models. In the definition, selection, abstraction and evocation inherent of the drawing, the landscape finds examples that enhance a picturesque narrative implicitly heralding misunderstandings and trivializations. But the same representation sometimes hides, in its different reading levels, a much richer interpretation, veiled to who does not enter its path, a new dimension that relates to reality by juxtaposing further levels of complexity and contradiction, further strengthening the logic of 'superadjacency' for which 'the more is not less' [Venturi 1967, p. 16]. The research on the landscape want to 'vertically' concern the great paradigmatic themes in their complexities and contradictions, and 'horizontally' they are concerned by minor themes aimed at narrating that inclusive character of the landscape, which is vital and paradoxically charged with its quality as a "hybrid, compromise, distorted, ambiguous, boring, conventional, accommodating, redundant, rudimentary, inconsistent, equivocal" [Venturi 1967, p. 16]. The complexities and contradictions in the landscape are then linked to the diachronic reading inherent in the stratification of signs and meanings, in the interpretation of values. This theme brings to search for the roots of the reasons for the current results and the suffered impairments, but which also opens up to philological considerations on the impact of Venturi's research. Without ever forgetting "the commitment to strive for difficult unity" [Venturi 1967, p. 16] the complexity and contradiction of the landscape wants to open up to socio-cultural issues of great relevance and far-reaching. These concern, among other things, the issues inherent in the theme of identity expressed in the landscape, the role of images and the value of perception in the world transformed by digital, the identification of identity elements, almost "transitional", of the landscape and in general its balance with the territory and the environment, which brings to recompose its totality in the narration of our places, a great theme of an operational policy on common goods.

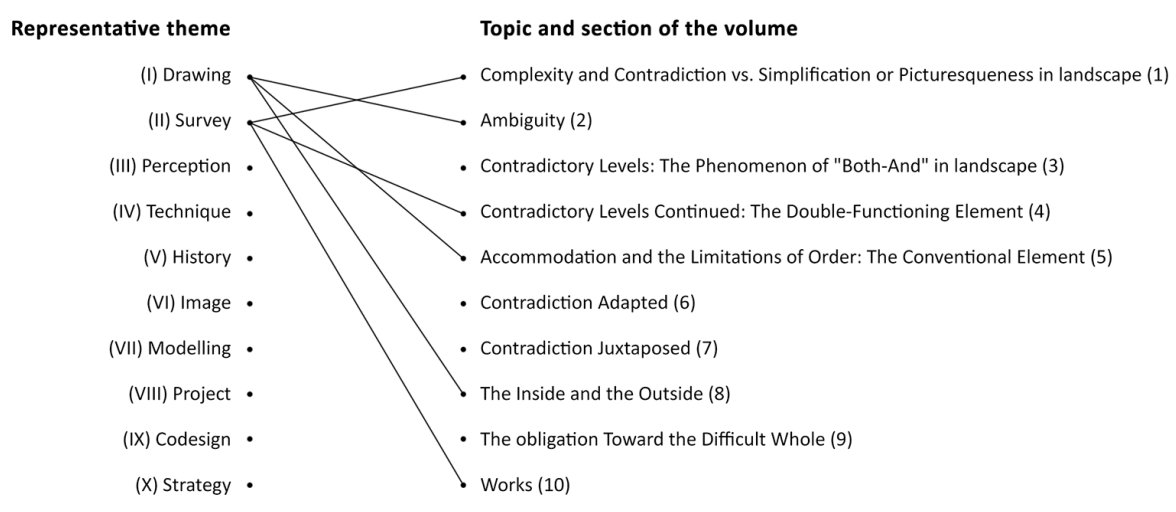

\section{The results of the proposal}

The volume consists of 43 essays, by 81 authors from all continents, from 30 universities, of which 17 are Italian. The articles are divided in four parts: a first section that analyzes the theme of landscape in contemporary society in relation to the interpretative categories proposed by Robert Venturi. A second section that marks its methodological and instrumental issues in relation also to representation and digital values. A third part that reinterprets different landscapes of the world and the aesthetics design according to complexity and contradiction. At last, a collection to return to Italy, guided by the words of Robert Venturi to enter the qualities and meanings of the multiple landscapes, so rich in the value of time stratification.

It is impressive to see, in this regard, the multiple interpretations that converge, however on similar directions, of illustrious authors such as Franco Purini, Franco Zagari, Denise Rae Costanzo, Carolina Vaccaro, Rosalea Monacella, Bridget Keane, Pilar Chías, Mario Torelli, as well 
as almost fifty scholars related to the area of drawing: everyone sees a substantial rediscovery of the contemporary nature of Robert Venturi's thought, as a real anticipation of landscape issues, in those years completely ignored. Furthermore, there are similar conceptions of landscape, in its multiplicity of forms, always complex and contradictory, where connections are structurally the very essence of what exists only as theory, in the etymological sense of the relation between 'seeing' and 'thinking', in the impact of the environment on man.
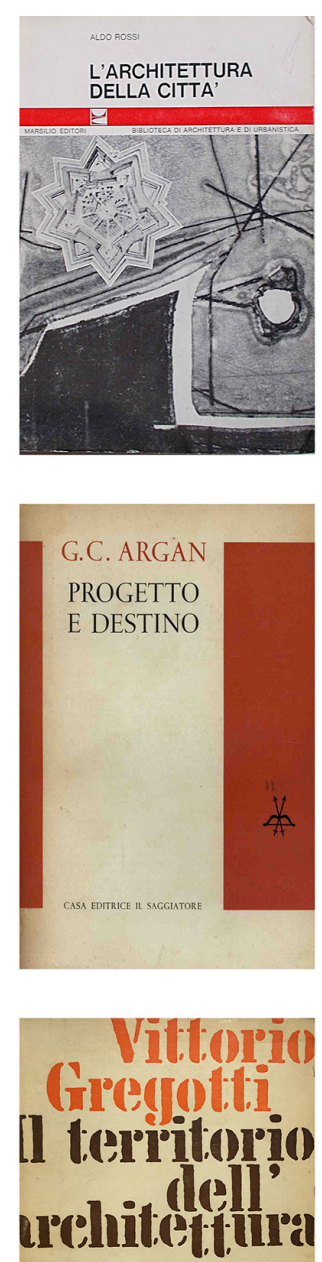

Fig. 3. Cultural connections in the flowering of master pieces of Italian architectural criticism in 1966.
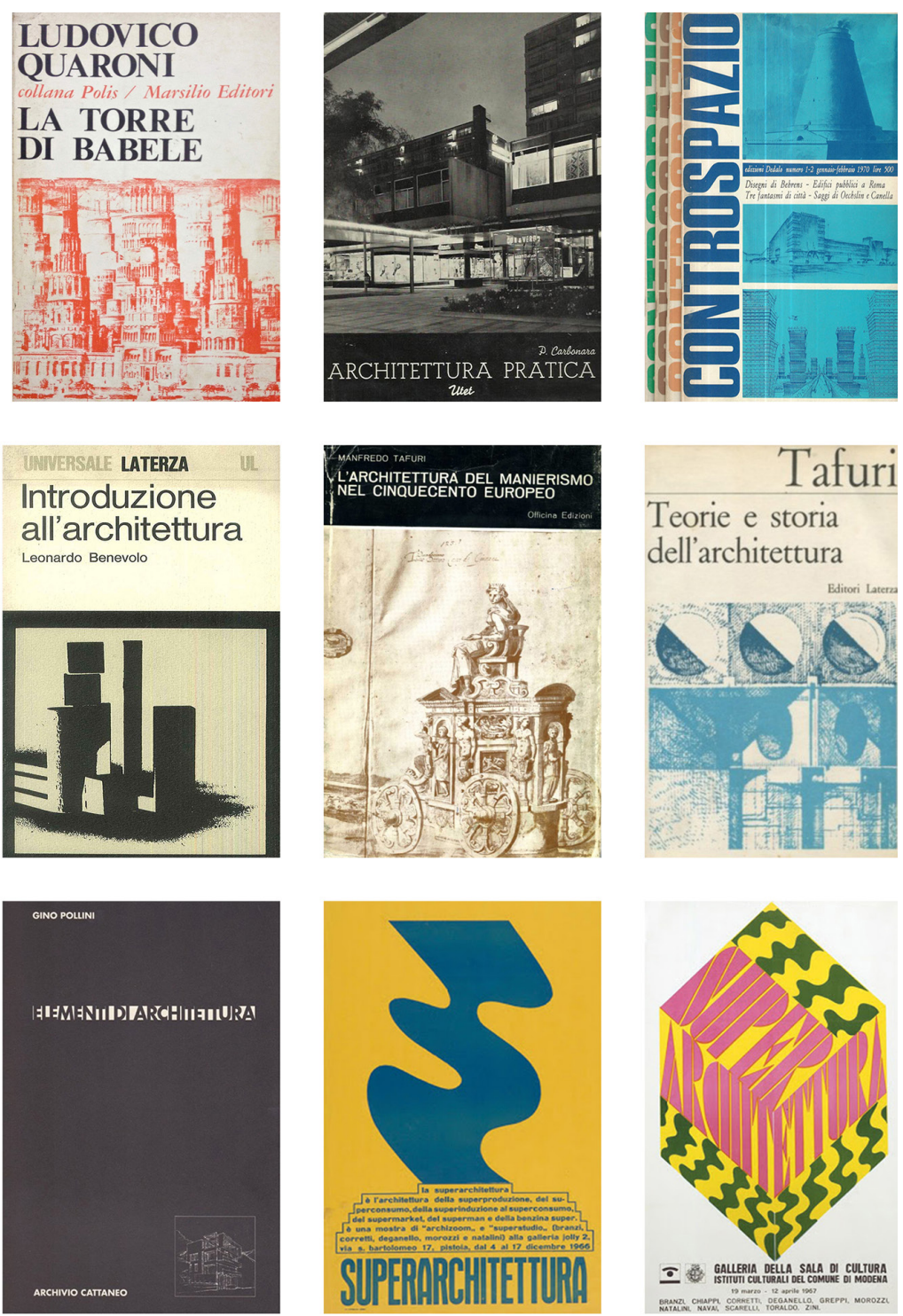

The connections in the connections

This call on connections as a representative theme of the landscape in relation to the reinterpretation of RobertVenturi's thought comes was born from the Italia region of Umbria. And, it is very interesting, in reading the connections in the connections, to understand that the thought of the then young American architect was born from his journey in Italy [Stierli 2007, pp. 42-63], from the charm, attraction and influence that this landscape had on him [Sessa 2017, p. 55], who was born of an Italian father and mother [Brownlee, Venturi, Scott Brown 200 I]. 
From protracted research, it is clear that Robert Venturi went to Perugia on a first trip in 1948 [Weller 1985, p. 100], and on this experience he describes this city as "a beautiful old city in an amazing location on its hill from which you see fantastic views: the Umbrian landscape is just that weird and very beautiful. It is like that background you glimpse in some 15th and 16 th century paintings -Perugino especially [...]. The combination of little towns $[\ldots]$ and trees $[\ldots]$ and orchards [...] and blurred hills in the background looks like what a child's concept of a landscape can be- or a painter's" [Sessa 2017, p. I31]. This first visit will be followed by the longest stay from 1954 to 1956 [Milovanovic-Bertram 2007] at the American Academy, a prestigious institute that will influence American architectural culture [Costanzo 2009], and in this period he will also visit Umbria, still underlining its landscape: "The Umbrian landscape, fantastic -somewhat the result of the entire landscape's being used for functional, agricultural purposes -its uses being adopted with grace. This area and its hill towns, like Assisi and Perugia, called to mind Frank Lloyd Wright's comment: "Of joy in living, there is a greater proof in Italy. Buildings ... seem to be born like flowers by the roadside. [...] They inspire us with the very music of life. No really Italian building seems ill at ease in Italy. All are happily content with what ornament and color they carry as naturally as the rocks and trees [...]. Wherever the Cyprus rises like the touch of a magician's wand, it resolves all in it in a composition harmonious and complete" [Sessa 2017, p. 142].

Fig. 4. Disconnections between the picturesque image of Umbria of the nineteenth century engravings and the construction of the landscape of the early twentieth century created through the work of man.
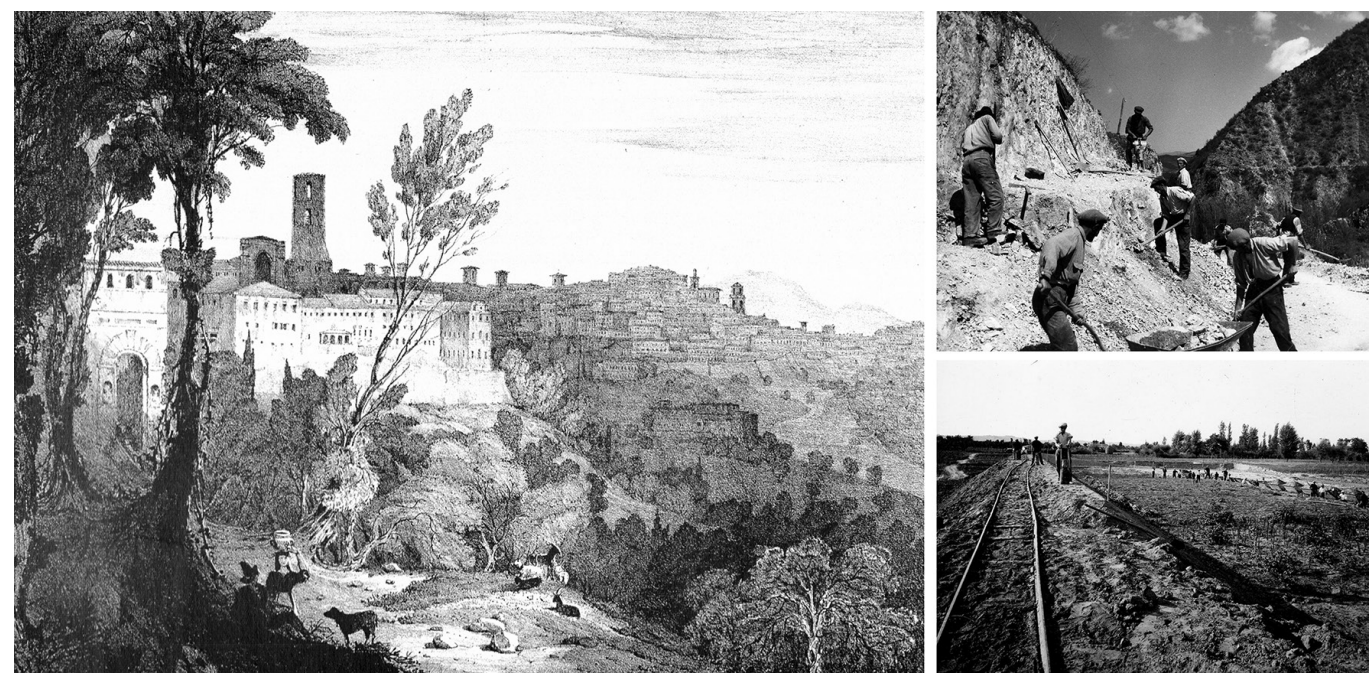

With biases, it can be said that RobertVenturi finds in this region a special place that leads to profound reflections on landscape. Umbria has enriched the eyes of the American master with images that have contributed to writing the history of architectural criticism, and which today claim their seductive genesis.

In the stratification of signs and meanings, these places certainly were Robert Venturi's "masters", and he implicitly imposed a comparison with the images of the memory of the places he saw or imagined [Milovanovic-Bertram 2007, p. 5]. Paradoxically, the landscapes of those years were deeply "picturesque", characterized by great contradictions, rich in historical pre-existences that today would have been considered with a greater respect. Then, those existences were dealt with great irony by the spontaneous popular dynamism, so well narrated by the images of Pier Paolo Pasolini, and today testified by Matera, the European capital of culture 2019 because it was saved from the "aesthetic of poverty" in the adaptive reuse of its landscapes [Arminio 20/3]. 
Free from that emotional relation that conditions those who live their native landscape, certainly influenced by Jean Labatut's [Scott Brown 1984, pp. 69-8I] phenomenological interpretation with his predominantly visual approach [Otero-Pailos 20 I0, p. 28], the themes opened by Robert Venturi are now extremely contemporary. As in the complexity of perception, the inherent contradiction in the replicated and exalted images in the media and in their languages, the underlying immaterial relations, the multiplicity of meanings that contest the pre-established dogmatic vision.

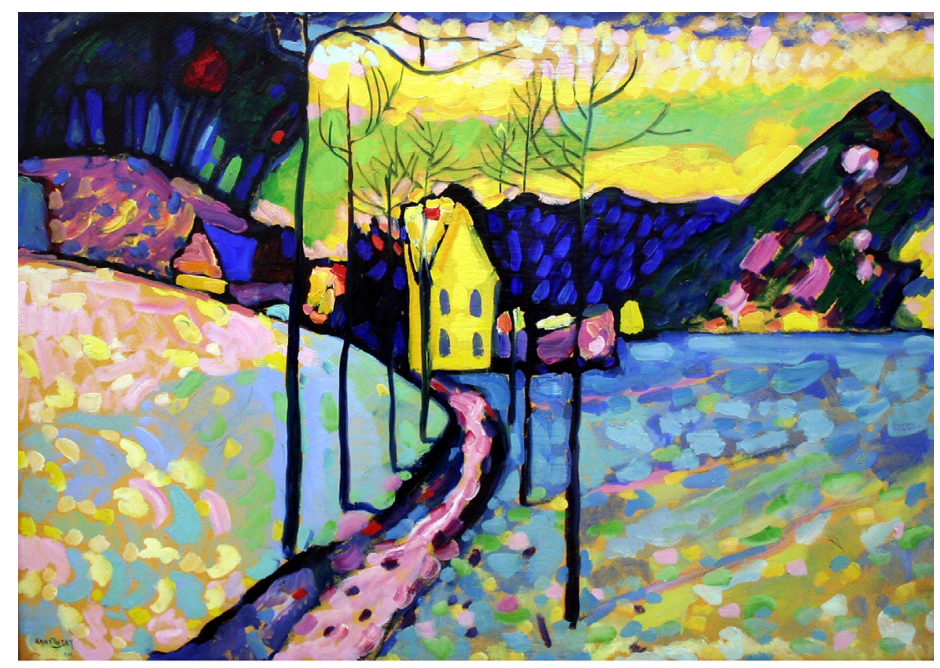

Fig. 5. Artistic connections between the reinterpretations of the landscap Mondrian ( $|9| 1)$. Mondrian ( $|9| 1)$

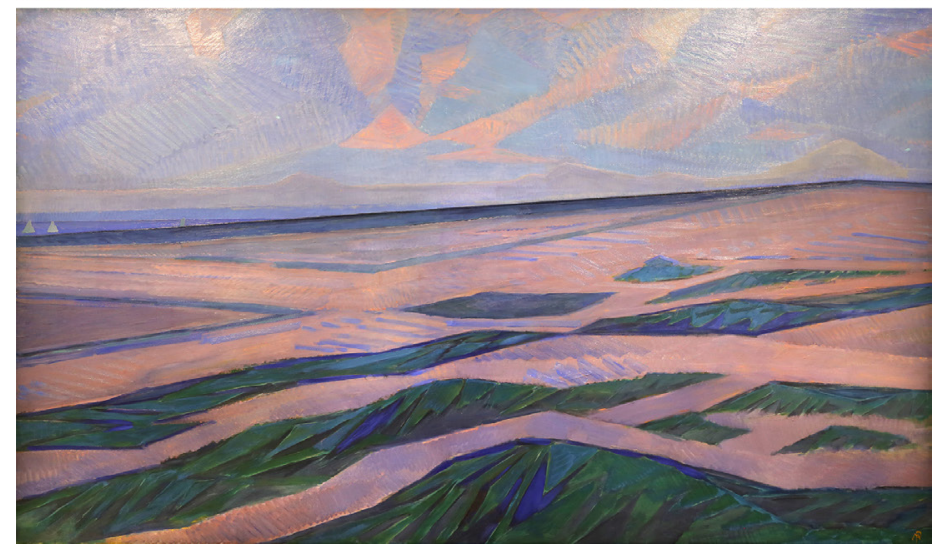

The other impressive connection in the connections is inherent in the architectural criticism coeval with Venturi. In particular, it is important to highlight that the first edition of Complexity and contradictions in architecture was written in the period 1962-1964 and it appeared in a new series called Papers on Modern Architecture published under the imprimatur of the New York Museum of Modern Art (MoMa) in 1966 [Ockman 2016]. It is no coincidence that there are impressive cultural connections with what happens in that exact same year in Italian universities: in Venice Aldo Rossi published The architecture of the city [Rossi 1966], a real best seller "translated into almost all European languages, basis of study and discussions in the all schools of Europe and America" [Rossi 1995, p. 5]. In Zevian Rome, Ludovico Quaroni published Five chapters of notes on the drawing for the city [Quaroni 1966] from which the famous volume The Babel Tower [Quaroni 1967] will be born, Pasquale Carbonara republished its Practical Architecture [Carbonara 1966], the young Paolo Portoghesi founded the magazine Controspazio (Controspazio. Mensile di architettura e urbanistica, 1966]. During that same year, Leonardo Benevolo republished his 
Introduction to Architecture [Benevolo 1960a; 1966a] and the famous History of Architecture [Benevolo 1966b; 1960b]. At the same time, Manfredo Tafuri, perhaps the first to enter in the value of the contradiction for architecture implicitly evoked in the complexity of the urban scale through utopia [Tafuri 1966a], wrote The architecture of Mannerism in the European Sixteenth Century [Tafuri 1966b].This text anticipated by two years the famous Theories and history of architecture [Tafuri 1968], for which it was used as the cover a 1966 design by Franco Purini, which had just opened his studio in that same year. At the same time in Milan, Vittorio Gregotti published the famous The territory of architecture [Gregotti 1966], Gino Pollini published his notes on the Elements of architecture [Pollini 1966], while in Florence, immediately after the great flood, in that year the was founded Superstudio and was inaugurated on December 4th the Superarchitecture exhibition in Pistoia.

These are not coincidences, but connections, new concepts at the base of architecture and landscape.
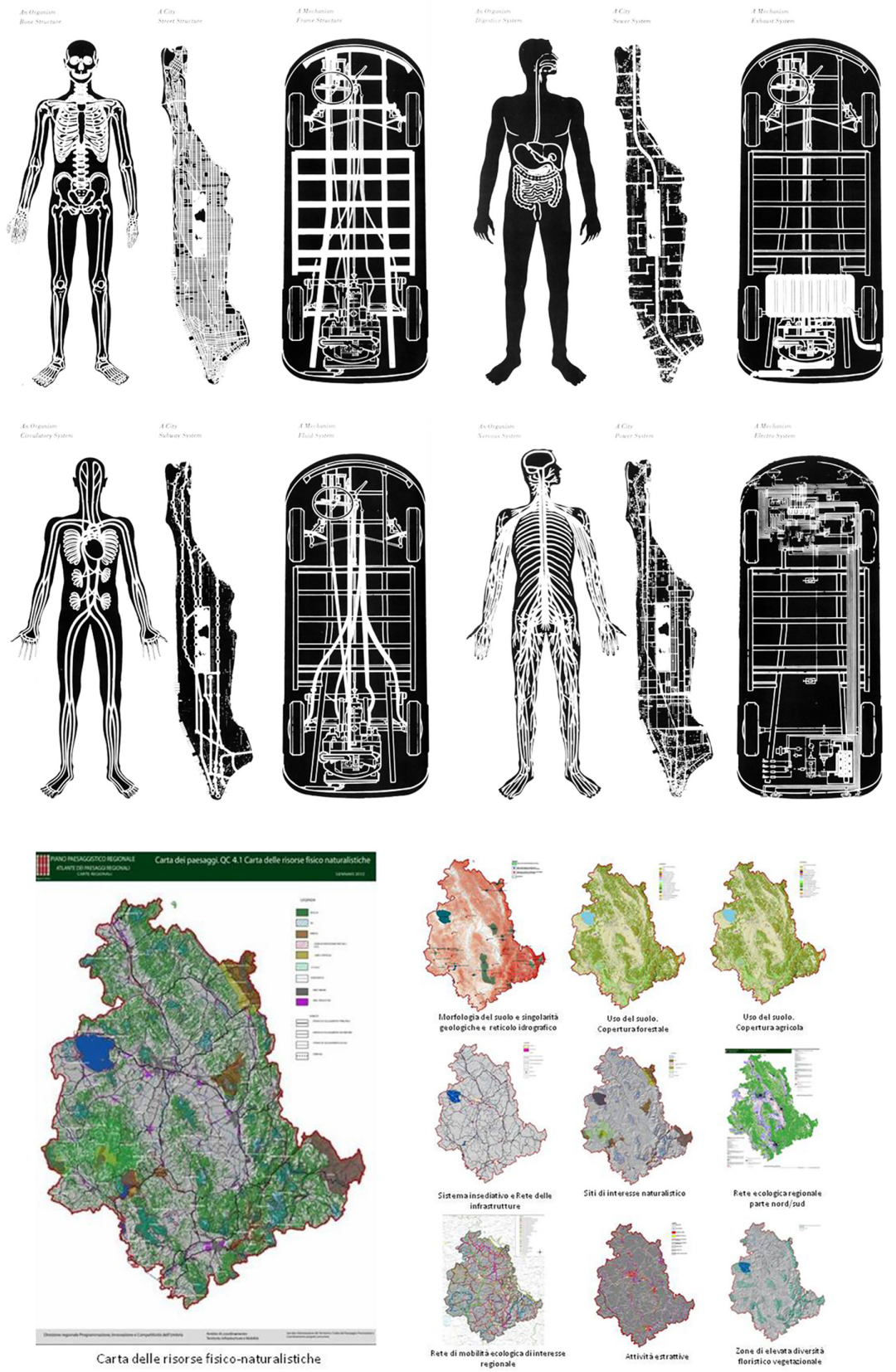

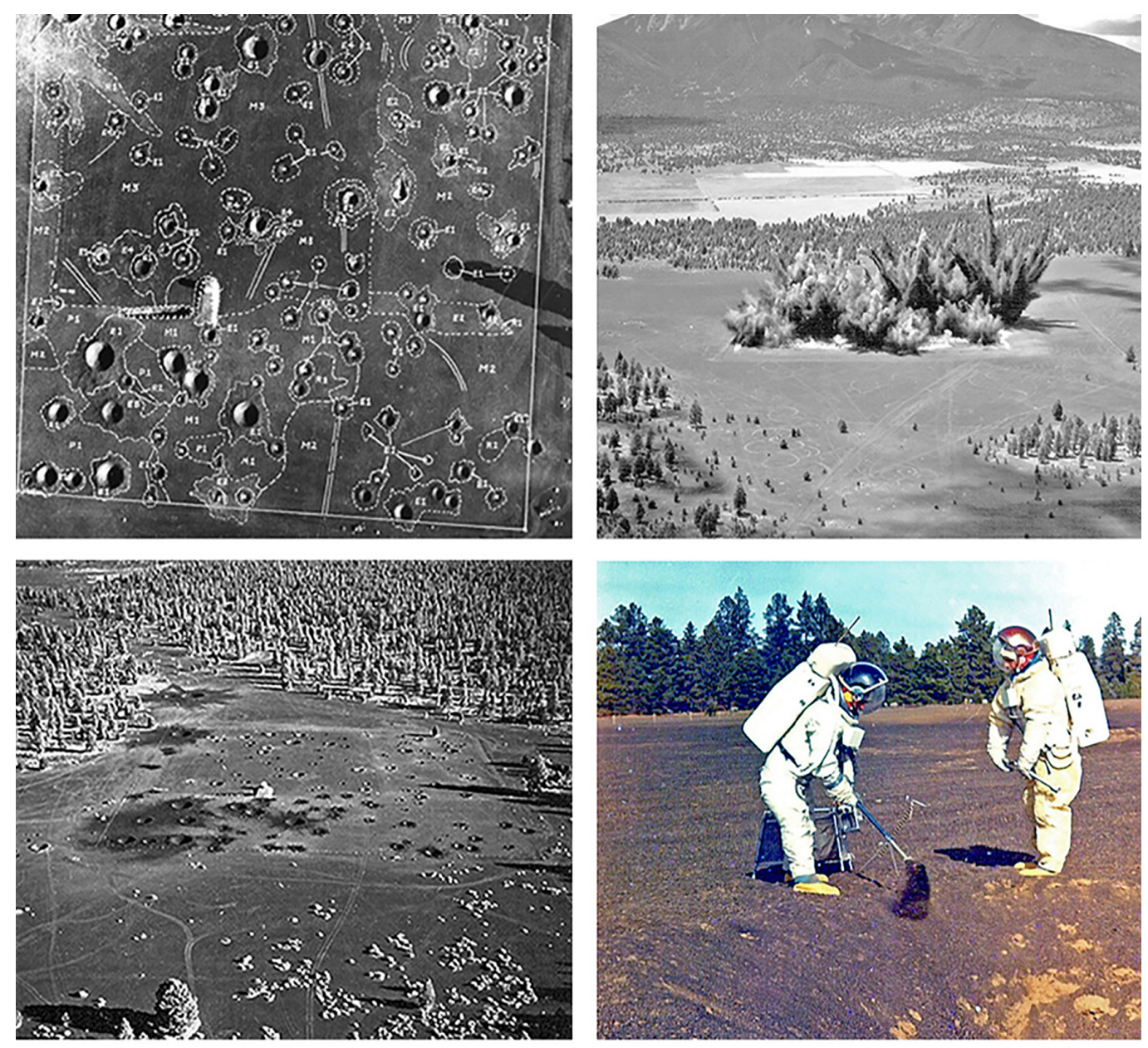

IMMAGINE DA SOSTIT

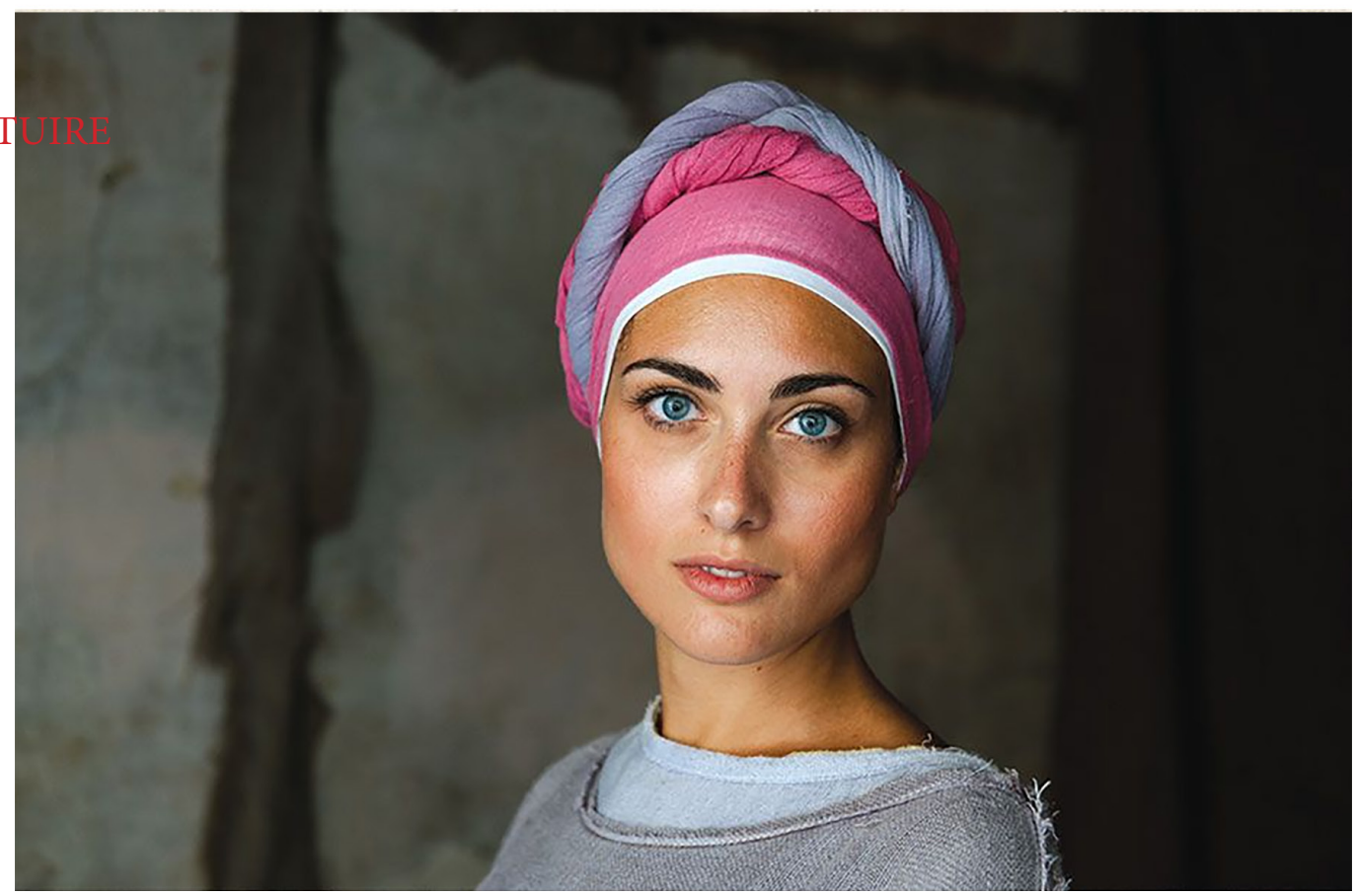


Fig. 8. Media connections between the image and landscape in advertisements within Venice and the implicit advertising re-proposition of Venice in Las Vegas.

Fig. 9. Formal connections between the city as a system of signs in the comparison between the urban composition

Pollack's drawings

Pollack's drawings
(Number 8, 1949)

Fig. 10. Representative connections between the urban landscape of Rome as a recomposition of mages in the etching of Giovanni Battista Piranesi on the fragments of the Forma Urbis (1756), the mnemonic islands of the "naked city" reinterprete by the theory of drift by Guy Debord (1958) and the social and functional analysis of the map of London (1943).
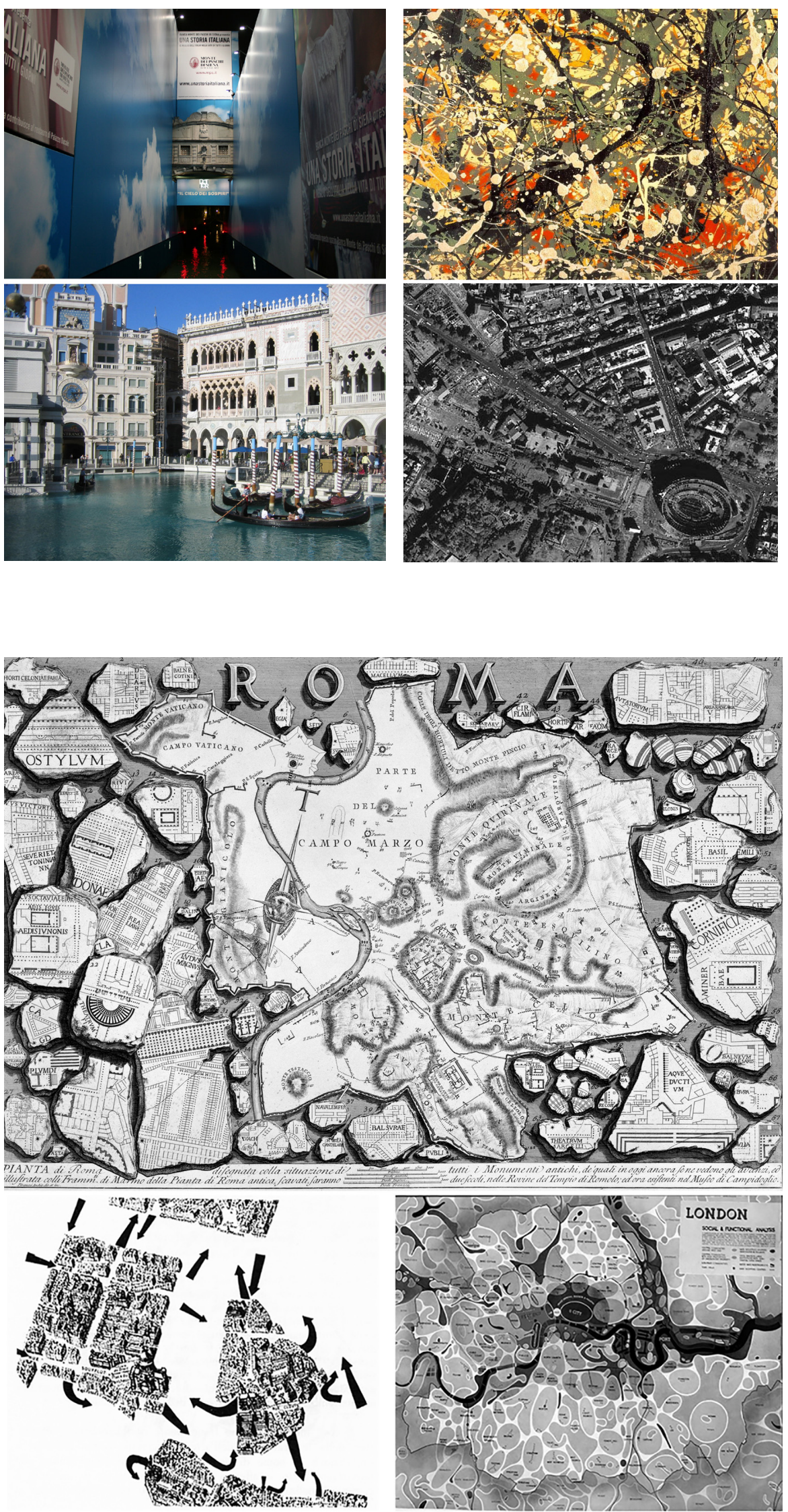


\section{Conclusive considerations}

Jim Venturi, son of Bob and Denise Scott Brown, is preparing the presentation for the volume. The vision of young Robert Venturi appears as a last will for the whole scientific community, re-evaluating a work that, with a subversive approach, breaks certainties and preconceptions, opening up to re-readings on purely contemporary issues. Strengthened by his cultural background of perceptual centrality, his ever-current lessons re-read the landscape correlating it with narrative logics, opening up to fields of investigation on traced paths. Taking also as a paradigmatic case the cover of Venturi's volume and his photographic representation of Porta Pia, though drawing, and in particular with the digital, it is possible to read in a new way the signs in the relation with space, with the constant evolving urban landscape.

Fig. II. Connections between images, symbols and semantic recompositions in the project for Rome by Robert Venturi's Rome by Robert venturis group (Robert Vent John Rauch, Steven Izenour and Denise Scott rown, 1983, Mixed technique and collage on paper, $70 \times 50 \mathrm{~cm}$, Francesco Moschini permanen collection and Gabriel Vaduva, AAM Modern Art Architecture).
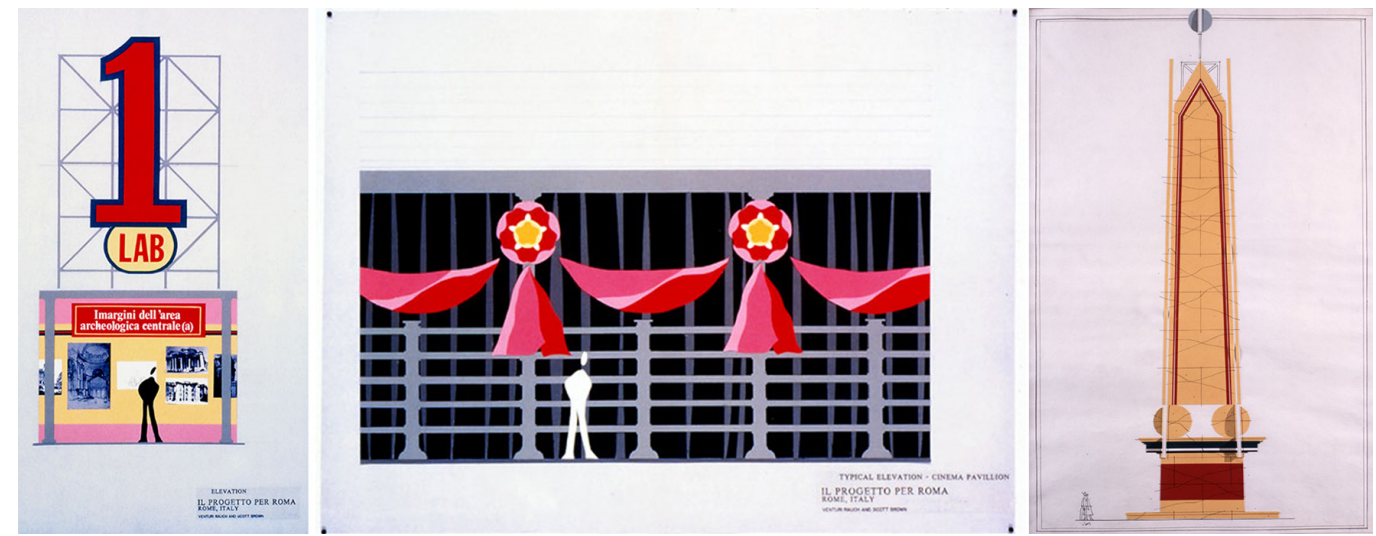

Robert Venturi is not a landscape painter, the volume focuses on the architectural scale and it presents only timid hints to the urban, not landscape scale. Yet, his vision dynamically opens to the interpretation of contemporary logics, teaching 'how to see' and it extends with disarming simplicity to open up to operational logics on landscape policies. By analyzing the landscape plans, it is possible to find that on the one hand binding logics connected to schematizations on what the landscape should be, therefore on picturesque projections, which are also manifested in the representations, as testimonies of a culture, limited to planimetric readings, which read the territory but actually tell little about the qualities of the landscape. As a counterpart, in dissociated forms, there are representations that implicitly enhance the picturesque, with attention to the visual not structured by information. From these concepts, the logics of territorial marketing and tourist promotion follow, where the landscape loses its quality as a cultural asset to become a product to "sell the territories", with a use of the seduction of the image that elides the protection and enhancement of those unsuitable places to fill magazine covers.

Representative researches are shown in this context for the methodological seriousness of the investigations on the connections that define the landscape. The virtuality inherent in multiple relations is combined with the transdisciplinary language of drawing, capable of guaranteeing the multiplicity of meanings even when entering in complexity and contradiction. The qualities of the place are transfigured in the design in its multiple declinations and experiments. In the representative researches that enter in complexity and contradiction, that courageously face the ambivalences of the multiplicity of meanings, new horizons of investigation are opened to understand the connections, immaterial relations that blend well in the logic of digital, but which are the very substance of the design, which proposes itself as privileged field of research for landscape interpretations. 

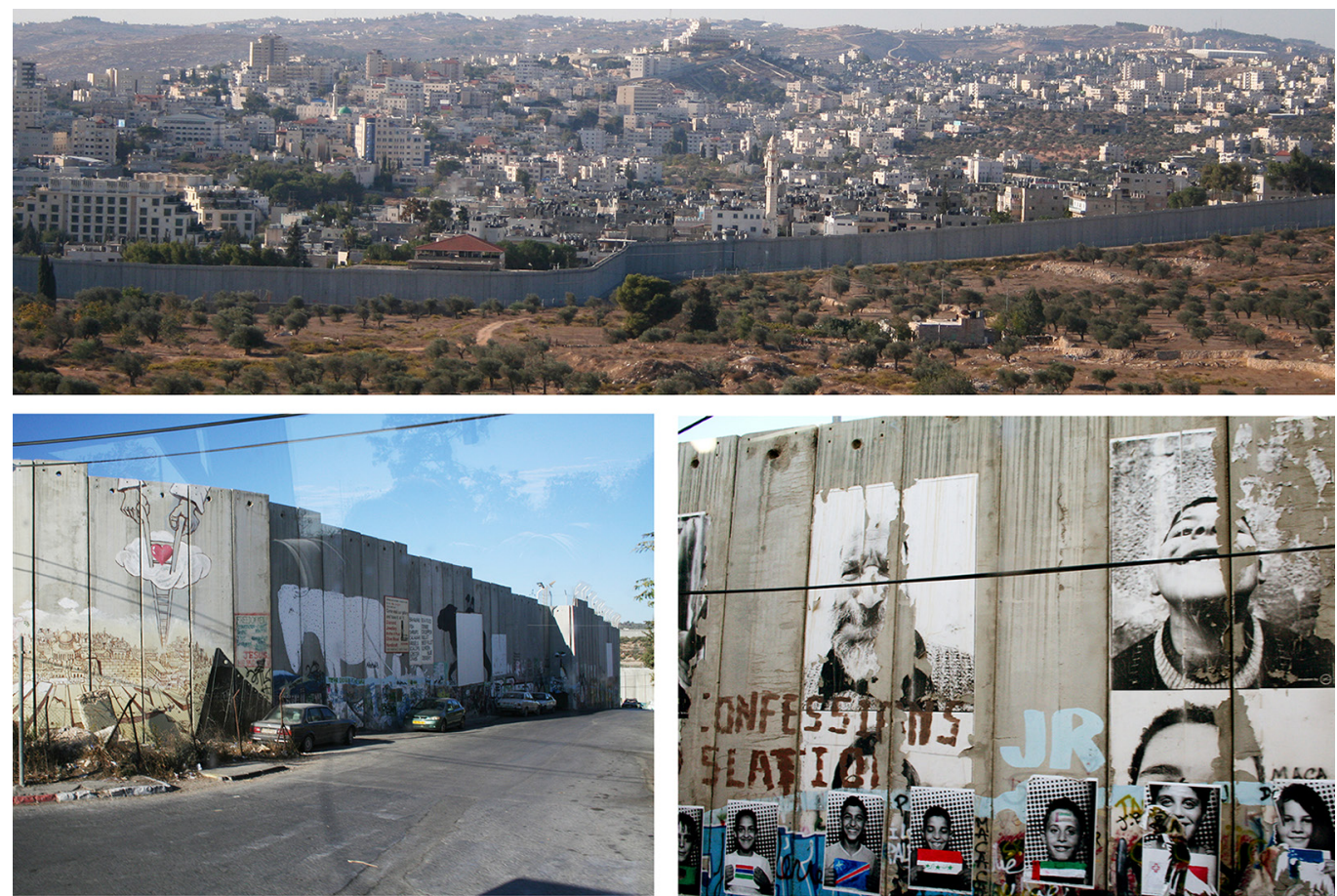

Fig. 12. The connections of representation

towards the landscape to

overcome the modern

limit of the division in

Bethlehem.
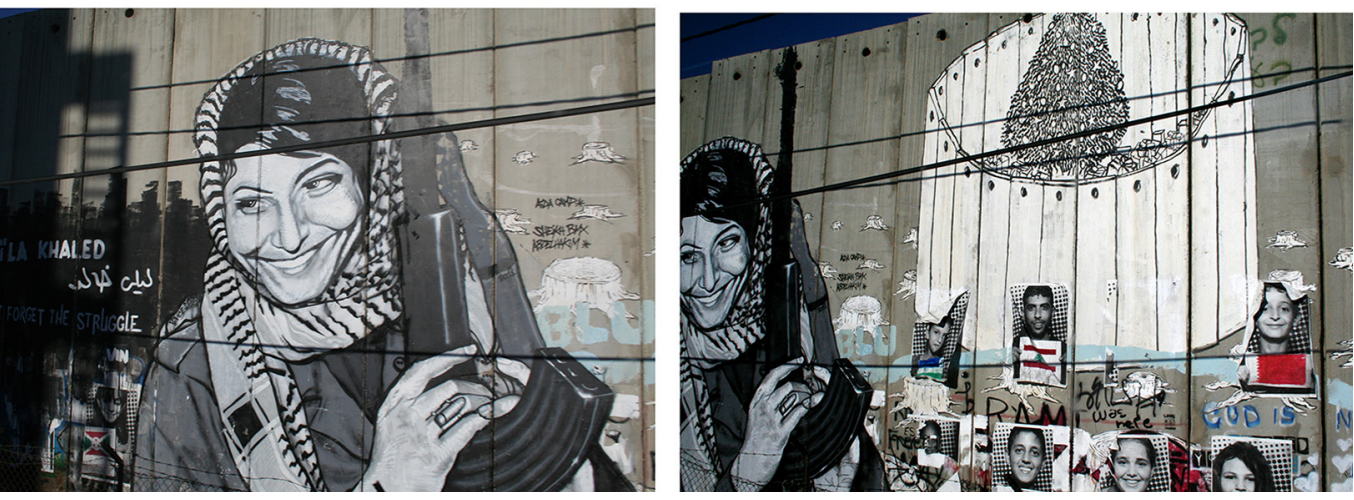

References

Argan Giulio Carlo (1965). Progetto e destino. Milano: II Saggiatore.

Arminio Franco (20।3). Geografia commossa dell'Italia interna. Milano: Bruno Mondadori.

Benevolo Leonardo (1960a). Introduzione all'architettura. Milano: Laterza.

Benevolo Leonardo (1960b). Storia dell'architettura moderna. Roma-Bari: Laterza.

Benevolo Leonardo (1966a). Introduzione all'architettura. Bari: Laterza.

Benevolo Leonardo (1966b). Storia dell'architettura moderna. Bari: Laterza

Brownlee David Bruce,Venturi Robert, Scott Brown Denise (eds.) (200I). Out of the ordinary: Robert Venturi, Denise Scott Brown and Associates : architecture, urbanism, design. Philadelphia: Philadelphia Museum of Art in association with Yale University Press

Carbonara Pasquale (1966). Architettura Pratica. Milano: UTET.

Cennini Cennino (2003). Il libro dell'arte. Milano: Neri Pozza.

Costanzo Denise Rae (2009). The Lessons of Rome: Architects at the American Academy, 1947-1966. The Pennsylvania State University.

De Fiore Gaspare (1967). La figurazione dello spazio architettonico. Genova:Vitali e Ghianda.

Gregotti Vittorio (1966). II territorio dell'architettura. Milano: Feltrinelli. 
Milovanovic-Bertram Smilja (2007). Lessons from Rome: The Works of Robert Venturi, Tod Williams, Thomas Phifer, and Paul Lewis. Rome: American Academy in Rome.

Ockman Joan (2016). Review: Complexity and Contradiction in Architecture by Robert Venturi. In Journal of the Society of Architectural Historians, I December, vol. 75, n. 4, pp. 490-492.

Otero-Pailos Jorge (2010). Architecture's historical turn: phenomenology and the rise of the postmodern. Minneapolis: University of Minnesota Press.

Pollini Gino (1966). Elementi di architettura. Milano:Tamburini.

Quaroni Ludovico (1966). Cinque capitoli di note sul disegno per la città / Ludovico Quaroni. Roma: Istituto di Architettura. Facoltà di Architettura.

Quaroni Ludovico (1967). La torre di Babele.Venezia: Marsilio.

Rossi Aldo (1966). L'architettura della città. Padova: Marsilio.

Rossi Aldo (1995). L'architettura della città. Novara: CittàStudi.

Scott Brown Denise (1984). A Worm's Eye View of Recent Architectural History. In Architectural Record, vol. I 72.

Sessa Rosa (2017). By Means of Rome. Robert Venturi: prima del Post-Modern. Università degli Studi di Napoli Federico II.

Stierli Martino (2007). In the Academy's Garden: Robert Venturi, the Grand Tour and the Revision of Modernism. In AA Files, 56, 2007, p. 42-56.

Tafuri Manfredo (1966a). La nuova dimensione urbana e la funzione dell'utopia. L'Architettura. In Cronache e storia, n. 124 febbraio, p. 680-683.

Tafuri Manfredo (1966b). L'architettura del manierismo nel Cinquecento europeo. Roma: Officina Edizioni.

Tafuri Manfredo (1968). Teorie e storia dell'architettura. Milano: Laterza.

Valentine Lucia N., Valentine Alan (1973). The American Academy in Rome, 1894-1969. Charlottesville: University Press of Virginia.

Venturi Robert (1967). Complexity and Contradiction in Architecture. New York:The Museum of modern art.

Weller Anthony (1985). Travel Notes: Robert Venturi. The Golden Air of Rome. In Architectural Digest, n. 5, 1985.

Zuccaro Federico (196I). L'Idea de' Pittori, Scultori, et Architetti. In Zuccari Federico, Alberti Romano. Scritti d'arte di Federico Zuccaro. Firenze: Olschki.

\section{Authors}

Fabio Bianconi, Università degli Studi di Perugia, fabio.bianconi@unipg.it

Marco Filippucci, Università degli Studi di Perugia, marco.filippucci@unipg.it

To cite this chapter: Bianconi Fabio, Filippucci Marco (2020). Digital Draw Connection: la sfida culturale della rappresentazione della complessità e contraddizioni nel paesaggio/Digital Draw Connections: the cultural challenge of representing complexity and contradictions in landscape. In Arena A., Arena M., Brandolino R.G., Colistra D., Ginex G., Mediati D., Nucifora S., Raffa P. (a cura di). Connettere. Un disegno per annodare e tessere. Atti del $42^{\circ}$ Convegno Internazionale dei Docenti delle Discipline della Rappresentazione/Connecting. Drawing for weaving relationships. Proceedings of the 42th International Conference of Representation Disciplines Teachers. Milano: FrancoAngeli, pp. 298 I-3004. 